\title{
Las imágenes como un modo de acción: las estatuas de guerreros castreños
}

\section{Images as a mode of action: Warrior statues of Castro culture}

\author{
Javier Rodríguez-Corral* \\ Universidad de Santiago de Compostela
}

\section{RESUMEN}

La identidad social es siempre experimentada y representada en contextos específicos. Al tener un carácter procesual, se necesitan puntos materiales específicos de referencia en la forma de paisajes, lugares, artefactos y personas. Centrándose en las estatuas de guerreros castreños, este artículo reflexiona sobre el papel de estas imágenes y examina la importancia de estas formas materiales como un medio crucial a través del cual la identidad y sociabilidad son creadas, contestadas y resueltas.

\section{SUMMARY}

Social identity is always experienced and enacted in specific contexts. Due to its evolving character, specific concrete material points of reference in the form of landscapes, places, artifacts and people are always required. Focusing on warrior statues of the Castro culture, this article reflects on the role of these images and examines the relevance of these material shapes as an important medium through which issues of identity and sociability are created, contested, and resolved.

PALABRAS CLAVE: Cultura castreña, Edad del Hierro, escultura prerromana, agency, iconografía, estética, cuerpo, teoría de la acción, biografía cultural.

KEY WORDS: Castro culture, Late Iron Age, pre-roman sculpture, agency, iconography, aesthetics, ancient image, body, theory of action, cultural biography.

\section{INTRODUCCIÓN}

Uno de los principales problemas de nuestra manera de comprender el mundo material deriva de los

\footnotetext{
* Grupo de Estudio para a Prehistoria do NO Ibérico (GEPN), Dpto. de Historia I. Universidade de Santiago de Compostela. Praza da Universidade 1, 15782 Santiago de Compostela. Quisiera agradecer a Josefa Rey, Xulio Carballo, Leonardo Sanjuán, Howard Morphy y Chris Gosden los comentarios, la documentación y las facilidades que me han dado para escribir este artículo.
}

dualismos contemporáneos que gobiernan el discurso arqueológico: la mente es separada del cuerpo, la cultura de la naturaleza, los sujetos de los objetos y lo metafórico de lo literal. Esta concepción cartesiana es la responsable de los excesos representacionalistas en la interpretación arqueológica de las estatuas, haciendo que veamos estas formas materiales como un reflejo pasivo de ideas preexistentes y, por tanto, un producto secundario de la realidad social de las comunidades que las construyeron. La consecuencia inmediata, es que no nos hemos preocupado por ellas como objetos de propio derecho, sino por aquello que supuestamente se esconde detrás de sus formas materiales. Esto hace que nuestro principal interés sea des-cubrir qué idea quieren representar. Sin embargo, las estatuas no sólo trasmiten un significado, sino que contribuyen activamente a producir significado, a mantenerlo, a reproducirlo, y a crear las condiciones materiales para que puedan funcionar de diferentes formas en diferentes momentos. En este sentido, las estatuas de guerreros castreños se presentan como una oportunidad para considerar seriamente el papel que desempeñan las formas materiales de este tipo en las sociedades pretéritas. Mi propósito es explorar cómo estas imágenes construyen activamente su significado en el propio contexto de las formas materiales del castro y, cómo, en este proceso, su materialidad participa en la creación y mantenimiento de la identidad y la sociabilidad indígena. Superar las teorías que ven en el arte un mero esquema de representación, nos permite entender estas estatuas como un modo de acción $y$, por tanto, como imágenes que desempeñan un papel en el marco performativo del castro.

Sin embargo, antes debemos revisar los argumentos que, en mi opinión, han situado erróneamente a 
estos iconos en un contexto romano, y que han determinado en último término su interpretación. Su adscripción al siglo i d.C., se debe al hallazgo de varias estatuas con inscripciones, y a la suposición de que estos epígrafes se realizaron al mismo tiempo que las imágenes, utilizado la datación epigráfica como termini ad quos. Este argumento ha tenido gran peso historiográfico desde que Hübner (1871) lo utilizara a finales del siglo XIX para datar las estatuas en época julio-claudia y flavia. Así, Sarmento (1933: 207), al defender una cronología romana, afirma que "las inscripciones grabadas en algunas [estatuas], cierran la puerta a cualquier contestación”. En la década de los 80, ya con las dos nuevas inscripciones de Santa Comba y São Julião a su disposición, Silva (1981), Almeida (1982) y Alarcão (1988) reiteran la cronología epigráfica, y sostienen que las esculturas de guerrero son consecuencia de la romanización. Martins y Silva no dudan de la coetaneidad entre texto e imagen, sentenciando "que de ningún modo se puede[n] considerar una añadido anacrónico" (Martins y Silva 1984: 43). Si muchos de estos autores generalizan la fecha epigráfica al conjunto de todas las estatuas, Tranoy (1988: 224-225), a finales de esta década, adoptando una posición intermedia, se sirve de las inscripciones para distinguir entre imágenes prerromanas y romanas. En la actualidad, diferentes autores han seguido defendiendo la sincronía de las mismas, datando las estatuas por criterio epigráfico en la primera mitad del siglo i d.C., fecha que se ajustaría a mediados de ese siglo para la imagen de Santa Comba (Redentor 2008; 2009).

De igual modo, los textos epigráficos también han influido decididamente en la interpretación que se ha dado de estas imágenes. A partir de las inscripciones de Rubiás y de Meixedo, Hübner consideró que las estatuas son monumentos funerarios. Esta interpretación cala rápidamente en investigadores como Sarmento (1886: 246), Vasconcellos (1896) y Paris (1903: 71) que se suman a la opinión del epigrafista alemán. De esta manera, a partir 1973, al descubrirse in situ los pies de un guerrero en una de las entradas del castro de Sanfins, se abandona la hipótesis que afirma que son monumentos que se colocaban sobre las tumba, lo que no ha impedido, que en la actualidad, se siga defendiendo su carácter funerario (Koch, 2003: 82). La interpretación como héroes epónimos divinizados, o divinidades tutelares de carácter votivo u honorífico, planteada desde el descubrimiento de los primeros ejemplares por Pereira (1908) y Maluquer (1954), es recuperada entonces por Tranoy (1988: 223), Almagro y Lorrio (1989: 418). Para Tranoy, las imágenes prerromanas representan héroes anónimos o divinidades tutelares, mientras que las estatuas con inscripción reproducen a jefes reales que lucharon probablemente en los cuerpos auxiliares romanos. En la misma línea, Alarçao (1988; 2003: 116) y Silva (2003: 47) ven en estos iconos los retratos de guerreros o príncipes históricos de la elite. Este último, tras analizar los epígrafes, defiende el carácter honorífico, y asigna a las estatuas una función heroizada de tutela "conectada con el culto a los Jefes y la glorificación de los antepasados típica de las sociedades basadas en los lazos de sangre como la cultura castreña" (Silva 2003: 47). Otros autores ven e ellas el retrato de príncipes o héroes locales que lucharon en las tropas auxiliares romanas y que fueron premiados por colaborar con Roma (Calo 1994: 685686; Peña 2003: 175-176).

Calo (1994) que, además de aceptar el criterio epigráfico, utiliza información arqueológica y contextual, ha interpretado estas imágenes -y las saunas castreñas - como una expresión del arte provincial romano, inspiradas en el programa escultórico que en esos momentos se erige en la ciudad de Bracara Augusta, opinión que comparte con Almeida (1986). De este modo, considera que la plástica y las construcciones con pedra formosa surgen en época romana (época julio-claudia), cuando una clientela provincial demanda unas estatuas y unos baños acordes a sus gustos, siempre limitados por la técnica y los medios disponibles, pero en último término, inspirados en las estatuas o las termas romanas. Las estatuas castreñas tendrían así su condición de posibilidad, en primer lugar, en una sociedad sometida a una "fuerte aculturación por parte de Roma"; y en segundo lugar, en la estrategia romana que alienta estas estatuas como un elemento más dentro de sus "planes de propaganda y asimilación" de las comunidades castreñas (Calo 1994: 806-807, 825-826; 2010: 260-265).

Dejando al margen el concepto de romanización implícito en estos autores, que ha sido deconstruido en los últimos años por diferentes autores (Woolf 1997; Scott 2003; Gosden, 2004; Hingley 2010), el uso del criterio epigráfico como forma de datación plantea serios problemas al ser francamente difícil demostrar que las inscripciones sean un elemento original de los guerreros. Igualmente, los datos arqueológicos esgrimidos para adscribir esta plástica al periodo romano no son en absoluto concluyentes, a pesar de que Calo afirme que "todas aquellas que se encontraron en un proceso de una excavación, en castros excavados o casualmente, pero asociados a algún material, nos lleva indefectiblemente al I d.C." (1994: 683). Lo cierto es que, exceptuando los pies de la estatua de Sanfins — que no aportan informa- 
ción cronológica-, no se ha documentado ninguna imagen de guerrero en contextos arqueológicos seguros que se correspondan con el momento de su uso primario.

\section{EPIGRAFÍA Y RECICLAJE SIMBÓLICO}

La sincronía del texto y la imagen, ya puesta en duda por diversos autores desde que se conocen las estatuas de Meixedo y Rubiás (Paris 1903; Correia 1924; Maluquer 1954: 68; Taboada 1965), carece de base argumental sólida (González-Ruibal 2006-2007; Rodríguez-Corral 2009; González-García 2009) y su asunción ha distorsionado y empobrecido nuestra comprensión de las mismas. La negación de la convivencia de elementos diacrónicos en un mismo objeto, impide que podemos apreciar como las historias asociadas con las estatuas han cambiado a lo largo del tiempo, reestructurando sus biografías culturales. Aceptar, empero, la diacronía entre el epígrafe y la imagen, nos ofrece una buena oportunidad para reflexionar sobre la relación que existe entre cultura material, identidad y tiempo (Rodríguez-Corral 2010) (Fig. 1).

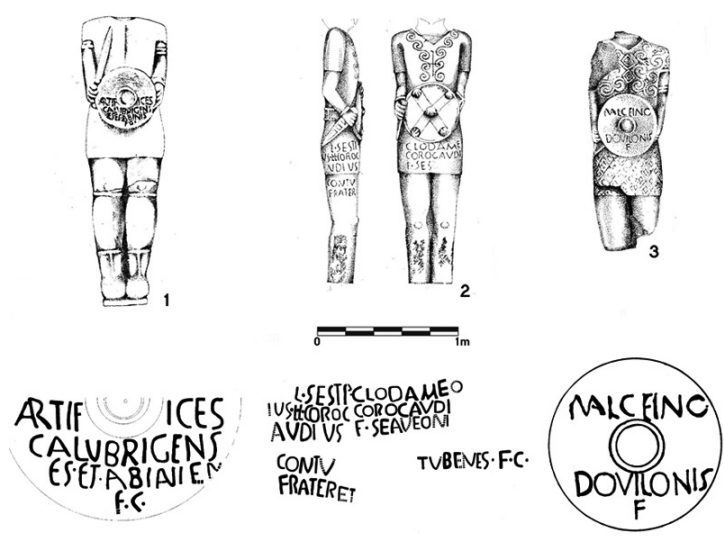

Figura 1. Estatuas con inscripciones romanas. 1. Santa Comba I; 2. San Paio de Meixedo; 3. São Julião.

Si las estatuas hubiesen sido concebidas como soporte de la inscripción cabe pensar que se hubiese preparado un campo epigráfico, pero no parece que esto ocurra. La estatua de Meixedo (Fig. 1.2) cuenta con tres áreas inscritas, una en la zona frontal ocupando parte del sago por debajo del escudo, otra en la parte del sago y la pierna derecha, y una tercera, en posición frontolateral, sobre la pierna izquierda. Es evidente que cuando se labró el guerrero no se pen- só que fuese a soportar las inscripciones, lo que explica que fueran ubicados de un modo que ya Paris (1903) calificó de "bizarre". El propio Tranoy (1981: 351; 1988: 223-224) que, como acabamos de ver, asigna al periodo romano las estatuas con epígrafe, considera que en este caso, el texto se habría añadido a la imagen prerromana. Si es poco o nada probable la sincronía de los tres textos epigráficos con la imagen del guerrero, más extraño resulta aun, que autores como Redentor (2008: 198) que defienden la coetaneidad de la escritura y la escultura, sostengan que los epígrafes inscritos en diferentes áreas del cuerpo formen parte de un mismo texto, ya que demuestra que hubo que fragmentarlo para buscarle sitio.

En el caso del guerrero de São Julião, Tranoy afirma que existe un campo epigráfico preparado en el escudo, ya que la inscripción aparece más o menos ajustada a la superficie del escudo. Sin embargo, el umbo queda situado entre las dos primeras líneas del texto (Fig. 1.3). Asimismo, en mi opinión, que el epígrafe aparezca centrado no demuestra nada: en primer lugar, porque puede ser una consecuencia derivada del exiguo tamaño del texto y, en segundo lugar, porque su posición centrada en el escudo no es un criterio válido para establecer la coetaneidad entre el epígrafe y la imagen. Esta misma característica, como ha señalado González-Ruibal (2006-2007), se cumple en una inscripción realizada en época moderna en el escudo de una de las estatuas de Santa Comba y es indudable que no es coetánea al escudo (Fig. 2). De modo ilustrativo, el epígrafe del otro ejemplar de Santa Comba, al ser más extenso que el de São Julião es inscrito forzadamente en la parte inferior del escudo quedando la primera línea partida por el umbo (Fig. 1.1).

A la luz de estos tres casos, parece evidente que no existe ninguna pauta preestablecida en el modo de ubicar las inscripciones en las estatuas, a diferencia de lo que ocurre con la representación de los elementos iconográficos completamente estandarizados. Pero, si estas evidencias no fueran suficientes para defender la diacronía entre imagen y texto, basta añadir un último argumento. En una de las estatuas de Lezenho se ha documentado recientemente huellas de otra inscripción (Redentor 2008: 212, n. 8). Aunque su gran deterioro impide lectura alguna, resulta enormemente interesante, ya que ésta se superpone a la decoración de la pieza, siendo por tanto posterior al programa simbólico del icono.

Que actualmente de los treinta y dos guerreros documentados (Calo 2003), solo podamos constatar cinco casos con epígrafe, permite pensar que estamos ante la excepción y no la regla, y por tanto, ante casos 


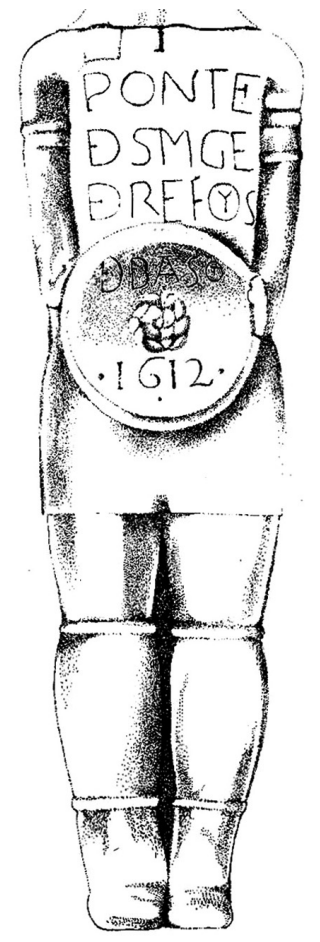

Figura 2. Guerrero castreño de Santa Comba con inscripción moderna de 1612. Ubicado en la plaza de Bastos en la actualidad, a finales del xIx se le añadió una cabeza (a partir de Silva, 1984). concretos de reutilización, singularización y reciclaje simbólico en momentos posteriores al uso primario de estas estatuas. El añadido epigráfico en un momento ulterior de la vida de una escultura o estela no debe considerarse algo extraño (Bradley 2002). Este tipo de formas materiales, por su tamaño, visibilidad, perdurabilidad y simbolismo, suelen sufrir cambios de contextos y fuertes procesos de resignificación, acumulando diferentes sentidos y funciones a lo largo de su biografía cultural (Gosden y Marshall 1999). Ilustrativo de esto es la cantidad de transformaciones, traslados, nuevas ubicaciones y significados que adquieren estas estatuas desde su creación hasta nuestros días, tal como aparecen recogidos en la obra de Calo (1994).

Con la introducción del hábito epigráfico, la escritura sirve como un eficaz mecanismo de reciclaje simbólico de objetos del pasado, muy especialmente para recontextualizarlos con un sentido funerario o votivo. Este hecho se constata no sólo en algunas esculturas de verracos del área vetona (Álvarez-Sanchís 1999: 215-294, 345-373), sino también en las estelas y estatuas-menhir del Bronce Final (Fig. 3). La estela de Chillón (Ciudad Real), en época romana, fue traslada a una necrópolis y reutilizada como marcador de una tumba. En la escena original se representa a un individuo con una espada y, a su lado,
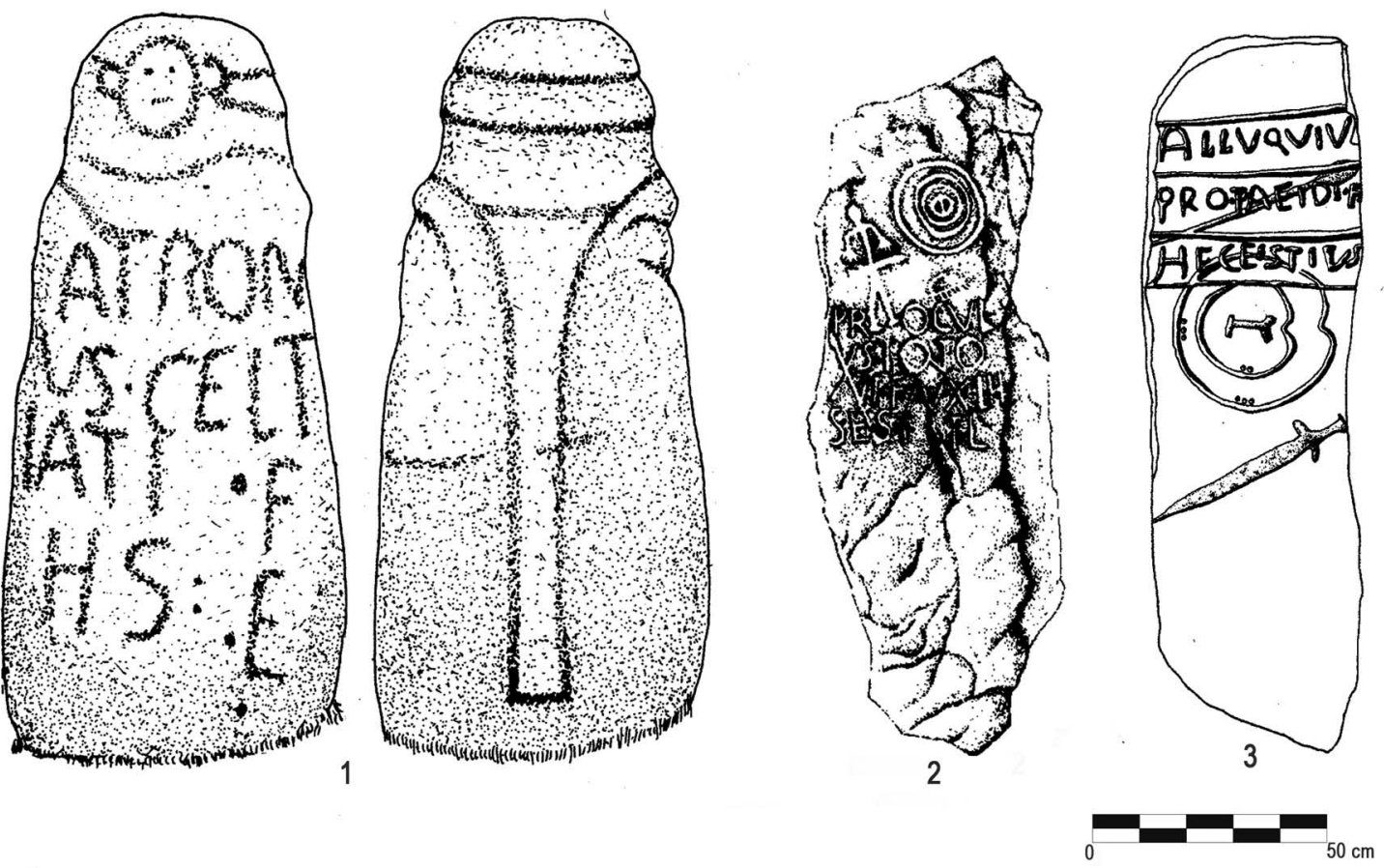

Figura 3. Epígrafes romanos sobre monumentos Prehistóricos. 1. Estatua-menhir de Muiño de San Pedro (Verín, Orense); 2. Estela de Chillón (Guadalajara); 3. Estela de Ibahernando (Cáceres) (a partir de García Sanjuán et alii., 2008 y Taboada, 1988-1989). 
a diferente escala, un escudo de tres anillos concéntricos, un peine y lo que se ha interpretado como una lanza. En el momento de su reutilización a esta escena se le añadió un texto que reza:

Procul/us Touto/ni F(ilius) An(norum) XLH(ic)/ S(itus) E(st) T(ibi) (Terra) L(evis)

Este epígrafe, al igual que los realizados sobre las caétras de las imágenes castreñas, respeta las formas y motivos originales del soporte. En este caso, como ocurre con la inscripción del guerrero de Santa Comba, el texto se interrumpe por un motivo primario: las piernas del individuo de la escena original.

Por otro lado, la estela de Ibahernando (Cáceres), en la que se representa un escudo con escotadura en $\mathrm{V}$, una espada y una lanza, también aparece reubicada en una necrópolis romana y se le añade una inscripción de tres líneas que se superpone a la parte superior del escudo. La trascripción es problemática porque tiene errores ortográficos, pero todo indica que el texto hace referencia a una persona de filiación indígena (García Sanjuán et alii, 2007: 19-120; 2008: 7-9; Fernández Ochoa et alii, 1994).

En la misma área donde se documentan las imágenes de guerreros castreños, se generalizan las llamadas estatuas-menhir durante el Bronce Final y principios de la primera Edad del Hierro. Se trata de un grupo escultórico perfectamente definido, que debido a su coincidencia geográfica con los iconos castreños, su forma antropomorfa y la representación en su superficie de armas, ha generado un debate a propósito de su relación con las estatuas castreñas (Calo 1994: 779-781). Una de estas piezas, la estatua-menhir de Muiño de San Pedro (Verín, Orense), al igual que las estelas de Chillón e Ibahernando, fue reciclada con una función funeraria inscribiéndose en su anverso el epígrafe:

\section{Latroni/us Celt/iati F(ilius) /H(ic) S(itus) : E(st)}

Siguiendo los mismos criterios epigráficos que para las estatuas castreñas, esta pieza (Taboada 1988) ha sido datada en la mitad del siglo I d.C. (Nodar 2004: 217), afirmándose en algún caso que se trata de una estela bifronte romana (Colmenero 1993). Sin embargo, el motivo subrectangular representado en su reverso, característico de las estatuas-menhir del Támega y el Duero, denuncia con rotundidad su filiación a las estatuas-menhir del Bronce Final. Si seguimos a Bettancourt (2005: 75-76), podemos afirmar que estamos ante una pieza que empezó siendo un menhir fálico, para más tarde, durante el Bronce Final, ser antropomorfizada y convertirse en una estatua-menhir que hasta finales de la Edad del Hierro debió funcionar como marcador de caminos. Es en el siglo i d.C. cuando se le añade un epígrafe y se reutiliza como monumento funerario, cambiando nuevamente de significado.

La distancia temporal entre la creación de estas estelas o estatuas y sus posteriores vidas es de gran importancia ya que ofrece a estas formas materiales una oportunidad para ser reevaluadas y, en el proceso, reintegradas en el mundo de una forma nueva, lejos del polo de producción donde el conocimiento del objeto fue más uniforme (Rodríguez-Corral 2010). De este modo, podemos interpretar la estatua-menhir de Muiño de San Pedro (González-García 2009) y las estatuas de guerreros castreños con epígrafes del mismo modo que las estelas de Chillón y Ibahernando (García Sanjuán et alii, 2007: 124; 2008: 10): como objetos resistencia en el contexto de aculturación romana del siglo i d.C. En un momento de ansiedad y de reconstitución de identidades en el noroeste peninsular (González-Ruibal 2006-2007), las estelasmenhir y las estatuas castreñas, reutilizadas en el ámbito funerario, pudieron encapsular ideas del pasado, memoria ancestral, sentido de pertenencia y, por tanto, una deliberada retro-ideología (Webster 2003; Aldhouse-Green 2004: 25-26).

A los responsables de esta reutilización, individuos indígenas como denuncia la antroponimia, la inscripción les ofrece un poderoso elemento para el recuerdo (Woolf 1998), haciendo que sus nombres puedan ser reactualizados a través de su lectura en momentos venideros. Pero la ejecución del epígrafe también les sirve como un eficaz mecanismo de apropiación, singularización y vinculación con un objeto que filtra temporalidades del pasado, permitiendo hacer de este, un pasado no ausente (Domanska 2006). En un mismo acto, pasado y presente están en juego: la reutilización de un objeto pretérito como monumento funerario que se le añade un epígrafe con su nombre, permite al individuo indígena negociar su identidad de un modo muy concreto en un contexto de discrepancia y reconstitución de la misma.

Con todo, estas estatuas, al alejarse en el tiempo de su contexto primario, pierden uniformidad semántica y se vuelven más ambivalentes, facilitando nuevos significados y usos que les permite tomar diferentes caminos biográficos (Kopytoff 1986). Sintomáticamente, a tenor de los epígrafes inscritos en las estatuas castreñas, el sentido de su reutilización en época romana pudo no haber sido exactamente el mismo en todos los casos (Redentor 2009). Asimismo, es posible que desde época flavia, extendida una nueva identidad romana imperial en el noroeste peninsular, las estatuas-menhir y las estatuas castreñas, que 
en los primeros momentos del siglo i d.C. habían servido para sostener una retro-ideología, ya no sean necesarias. Desde este momento, simplemente se amortizan. Así, la estatua-menhir de Chaves — que como la de Muiño de San Pedro, había sido previamente un menhir fálico - se reutilizan ahora como material de construcción en la obra del Puente de Aquae Flaviae (I-II d.C.) (Varela 1997: 270). Por otro lado, en Monte Mozinho, en época flavia y antonina, en donde se construyen casas tipo domus y un monumento bajo arquitectura romana, las estatuas de guerreros ya fragmentadas se amortizan, tal como certifican los pies de un guerrero, en la construcción de un enlosado (Almeida 1974: 9).

\section{HACIA UN CONTEXTO ARQUEOLÓGICO PRIMARIO}

A la luz de lo expuesto en el anterior apartado, si asumimos en primer lugar, la diacronía entre las inscripciones y los iconos, y en segundo lugar, que los epígrafes se realizaron en la primera mitad o mediados del siglo I d.C. (Redentor 2009), tenemos que situar el uso primario de los guerreros castreños antes de la fecha epigráfica, lo que invalida la datación para estos iconos en época julio-claudia como se ha venido sosteniendo (Calo 1994; 2007; 2010; Redentor 2008).

No conocemos contextos cronológicos y estratigráficos seguros que permitan datar con precisión las estatuas de guerreros, pero mucho menos que animen a adscribirlos a época julio-claudia. De hecho, la reiterada aparición de sus fragmentos en contextos modernos hace que la propia vinculación de algunos ejemplares a un asentamiento resulte imposible. Es el caso de las estatuas de San Jorge de Vizela y San Paio de Meixedo, amortizadas en construcciones modernas y de las que ni tan siquiera conocemos el castro de origen.

En otros casos, su vinculación a un castro es fiable. Sabemos, por ejemplo, que las estatuas de Lezenho proceden del Outeiro de Lezenho, ya que en los pedestales sobre los que fueron colocadas cuando se descubrieron, sendas inscripciones especifican que se hallaron en ese lugar en 1785 (Calo 1994: 302). Aun así, al no haberse llevado a cabo excavación alguna, carecemos de cualquier información contextual que nos permita datar las piezas. Diferentes son los casos de las estatuas de Cendufe y las dos de Santa Comba, que aunque también se vinculan a castros sin excavar, sus fragmentos han sido datados en el siglo i d.C. por asociación con materiales ro- manos (Calo 1994). En el primer caso, los fragmentos de la estatua se encontraban amortizados en construcciones modernas cercanas al castro y los materiales romanos que sirven de índice para su datación: una moneda de época de Nerón y otra de Claudio, fragmentos de columnas, ladrillos y la parte superior de un ara romana aparecieron en superficie dentro del yacimiento al que se vinculan las piezas. Si este tipo de materiales en ninguna caso pueden datar una estatua con la que no comparten relación espacial alguna, menos aún, si tenemos en cuenta que aparecen en superficie, mezclados con otros materiales de época visigoda. En el segundo caso, una de las estatuas de Santa Comba fue descubierta en la ladera del castro en el transcurso de trabajos agrícolas que también sacaron a la luz tégulas y cerámica común romana. Al igual que el material recogido en superficie, el salido de tareas agrícolas no parece que sea fiable para datar una escultura que con seguridad está fuera de contexto. En todo caso este material estará indicando el momento de abandono de la escultura y nunca su contexto de uso primario.

Diversos yacimientos a los que se vinculan, o en los que han aparecido, estatuas de guerreros, como Castromao, Monte Mozinho, Santo Ovidio de Fafe, São Julião y Sanfins, sí que suministran, aunque de modo desigual, información e indicios cronológicos que permiten, en mi opinión, situar el contexto de uso de las estatuas en un horizonte no romanizado durante el siglo i a.C.

En la parte alta y en el primer recinto inferior de Castromao se documentan los restos más antiguos de ocupación. En la plataforma superior y en el nivel de cimentación de la muralla se registraron cerámica Alpiarça, cerámica griega, fíbula de longo travessão sem espira, materiales que junto a las diferentes dataciones de C14 obtenidas en esta zona, evidencian un momento de habitación que transcurre entre el siglo vII a.C. y el siglo II a.C. En la plataforma media e inferior, protegida por la muralla, sucesivas reestructuraciones y superposiciones de estructuras trasformaron esta zona del caserío a lo largo del tiempo. En uso desde principios de la segunda Edad del Hierro pudo haberse prolongado hasta la primera mitad del siglo i d.C. Sin embargo, esta área no ha suministrado materiales romanos en las excavaciones de García Rollán (1971). Es en este momento cuando el castro se deshabita, y exceptuando una pequeña área intramuros cerca de donde se ubicaba la entrada del poblado (Orero 2007; 2008), ahora sus habitantes descienden a las laderas para vivir fuera de las murallas. Este proceso, que a tenor de una fecha de $\mathrm{C} 14$ (Orero 2000), podría haberse iniciado en el cambio 
de era, se generaliza desde mediados del siglo i d.C. a las tierras inmediatas al castro, exceptuando la ladera noroeste. Con el tiempo este nuevo hábitat extramuros terminará ocupando una extensión de 34 ha (García Rollán 1971; Orero 2000). Todo ello revela la paulatina pérdida de importancia de las murallas desde principios del siglo i d.C.

Los materiales que se documentan en las excavaciones más recientes de Monte Mozinho (Soeiro 2000-01: 107) revelan un hábitat indígena durante la segunda mitad del siglo I a.C. En época augusta momento de plenitud del castro, se construye la muralla que alberga un espacio planificado de 20 ha en donde abundan las casas de piedra de planta circular. Las jambas y los dinteles de algunas de estas cabañas están decorados con sogueados y cordados, y en sus muros se representan esvásticas y espirales. En estos momentos la vida de sus habitantes se realiza bajo un modo completamente indígena y prerromano, siendo el material foráneo producto de las relaciones de intercambio con el sur peninsular. Como en Castromao, a partir de mediados del i d.C. el asentamiento pierde sus características castreñas, la población disminuye y el espacio habitado se contrae. En algunas áreas, se arrasan las viejas estructuras para construir edificios al gusto romano. Se empieza a habitar fuera de las murallas, y entre finales del siglo I y principios del II d.C. se edifica en el exterior un monumento funerario romano. Las piedras decoradas son reutilizadas como material de relleno ya desde época pre-flavia y los pies de un guerrero castreño son amortizados en la construcción de un enlosado datado en el siglo III d.C. (Almeida 1974: 9, 29).

Otro asentamiento en el que se documenta estatuaria es Santo Ovidio (Fafe, Braga), situado en el valle del Vizela. La fijación humana en esta zona se realiza desde la Fase II (VI-v a.C.- II a.C.) (Silva 1986). Aunque no sabemos el momento exacto de la fundación del poblado, Martins (1991) lo sitúa sin lugar a dudas en un período anterior al siglo I a.C.; y durante este siglo, la fase álgida de crecimiento y transformación del poblado. Con todo, la parcialidad de las excavaciones no permite conocer las características del asentamiento durante la primera mitad del siglo i a.C. Los materiales más antiguos de los niveles de relleno del foso y de la primera pavimentación de la calle arrojan una cronología del siglo v-II a.C., siendo paralelizable, con la fase II A de São Julião. Las fosas se rellenan antes de la mitad del siglo i a.C. y a partir de las dos últimas décadas es cuando entra en funcionamiento la plataforma sobre la que se construyen la mayor parte de las estructuras de ha- bitación en esta área del poblado. Los escasos materiales romanos que se asocian a la plataforma - monedas de Augusto (algunas de la serie de la caetra), terra sigillata hispánica, y únicamente ánforas tipo Haltern 70-, son insuficientes para poder hablar de una proceso de aculturación romano y revelan un contexto indígena que mantiene contactos con la región romanizada del sur de la Península. La propia investigadora responsable de las excavaciones, asocia la escultura de guerrero al momento álgido de esta plataforma en la segunda mitad del siglo i a.C. (Martins 1991: 106-107).

El castro de São Julião suministra una secuencia de ocupación continuada desde el Bronce Final hasta el siglo I d.C., momento en el que se abandona el asentamiento. Los trabajos arqueológicos realizados en este yacimiento y en el entorno arqueológico del valle del Cávado permiten situar el gran desarrollo de los castros de esta región en la fase III; esto es, entre finales del siglo II a.C. e inicios del siglo I d.C. (Martins 1990: 148). En esta fase, y no durante época julio-claudia, es cuando se transforma y se monumentaliza, a través de un proceso similar al que ocurre en los castros de Barbudo, Terroso o Sabroso —este último abandonado antes del periodo de romanización pero en el que sin embargo se documenta piedras decoradas-. En São Julião durante esta etapa, y con anterioridad a cualquier señal de romanización, se uniformiza la cultura material, se levantan robustas murallas y se reorganizan los espacios domésticos. Hasta mediados del siglo I d.C. la cultura material romana documentada en el castro es escasa y en ningún caso responde a contextos de romanización sino de relación e intercambio con las comunidades romanizadas del sur de la Península, como testifica la escasez de ánforas vinarias a finales del siglo I a.C. y a principios del i d.C. algún fragmento de terra sigillata hispánica, y ausencia de cerámica común romana — como cabría esperar que se documentase en un contexto romanizado- (Martins 1990: 149).

Por último, la información que suministran las excavaciones de Sanfins también permite situar la fase álgida de este asentamiento en un momento anterior al cambio de era, concretamente entre las dos últimas décadas del siglo II a.C. y finales del siglo I a.C. Durante este período se documenta una rica cultura material constituida por fíbulas de diferente tipología - Sabroso, Santa Luzia, trasmontana o longo travessão sem espira-, un fragmento de torques, y abundantes elementos arquitectónicos decorados con trisqueles, trenzados o cordados (Silva 1986: 47). Esta fase de ocupación se caracteriza por 
un ambiente indígena —abundante cerámica prerromana- en contacto con las redes de intercambio que relacionan a las comunidades del noroeste con el sur peninsular — cerámica campaniense, ánforas, dolia, terra sigillata itálica-, en un contexto de rutas de intercambio que se remonta al comercio púnico como refrendan cerámicas púnicas del V-III a.C. halladas en el recinto interior del asentamiento (Silva 1999a: 25-26)—. Un fragmento de ánfora Dressel 1 depositado en el estrato de construcción de la muralla del primer recinto (Silva 1986: 47) data su construcción entre finales del II a.C. y mediados del I a.C., y por tanto en un momento anterior a Augusto. Junto a uno de los cortes de la primera muralla, aparece un tesoro monetario formado por 288 denarios republicanos cuyas cronologías van desde el 250 a.C. hasta el 28 a.C. Este se depositó cuando la muralla ya se encontraba construida (Paço y Jalhay 1955). El lugar del hallazgo y las piezas más modernas han permitido plantear que el tesoro fue escondido en un contexto de inseguridad como consecuencia de las guerras cántabras. Cerca de ahí, junto a la muralla, se localizaron dos quinarios de Carisius del 25 a.C. y 23 a.C. en un área quemada que sus descubridores han relacionado con un asalto al castro. Tras este acontecimiento parece que la vida sigue en el castro — como indica alguna moneda imperial, "pero las murallas no fueron rehechas, ni los escombros retirados" (Calo 1994: 474). A partir de Augusto la vida languidece, a tenor de las escasa terra sigillata hispánica que aparecen en niveles de abandono. Con el declive del poblado, sus murallas pierden valor, la imagen del guerrero que se ubicaba en la entrada al segundo recinto es desmantelada y a mediados del siglo I d.C. reubicada junto a dos aras anepígrafas en el interior de una construcción en la parte alta del castro.

En suma, a pesar de que no contamos con información contextual detallada que nos permita datar con precisión el contexto de uso primario de las estatuas castreñas - mucho menos el inicio de este-, sin embargo, en mi opinión, los datos arqueológicos resultan suficientemente reveladores de su naturaleza prerromana. En primer lugar, si exceptuamos Monte Mozinho, el resto de los asentamientos a los que se les asocia estatuaria están funcionando como mínimo desde el siglo II a.C. En segundo lugar, el desarrollo y expansión de estos castros tiene lugar antes del cambio de era; en Monte Mozinho esto ocurre en torno al 30-20 a.C., mientras que en Sanfins se constata desde finales del siglo II a.C. En tercer lugar, este proceso de transformación, reordenación y reestructuración de los sistemas defensivos sucede en un ambiente completamente indígena, sin señales de romanización, y en contacto con las redes de intercambio atlánticas con el sur de la Península. Y en cuarto lugar, es en el periodo julio-claudio, al que se asignan normalmente los epígrafes, cuando la vida intramuros en Castromao y Monte Mozinho decae y se habita fuera de las murallas, momento en el que éstas pierden su papel defensivo y su valor simbólico; lo que explica que en Sanfins se retire de la muralla la estatua del guerrero.

Nuestro siguiente paso, por tanto, es volver a pensar el posible sentido y papel que estas estatuas pudieron desempeñar durante el siglo I a.C. en un contexto donde las comunidades castreñas crecen, rehacen sus castros, se llevan a cabo programas de monumentalización de los asentamientos, se intensifican sus relaciones de intercambio con otras zonas de la península y, por supuesto, entran en contacto con Roma, presente en la zona desde finales del siglo II a.C.

\section{SIGNIFICADO Y TEATRALIDAD}

Como ya anticipe, el problema principal que arrastran las interpretaciones de estas estatuas es su fuerte sentido especular. El interés fundamental pasa por descubrir qué reflejan o qué significado esconden tras ellas — saber si son héroes divinizados, deidades tutelares, guerreros o príncipes históricos-. Estas interpretaciones asumen por tanto una noción de las imágenes como un reflejo pasivo de la sociedad o de las creencias de estas comunidades. En mi opinión, este hecho se debe al excesivo peso que en arqueología han tenido las aproximaciones iconográfica y epigráfica, que tradicionalmente han obviado los aspectos sinestésicos y performativos de la cultura material. Las imágenes de los guerreros castreños no sólo representan algo, sino que actúan, creando realidad social. Como expresión artística son modos de acción específicos (Morphy 2009) que funcionan en un contexto concreto: el colectivo de formas materiales del castro que crean las condiciones de posibilidad de la sociabilidad indígena. Por tanto, no debemos preocuparnos tanto por lo que representan, sino preguntarnos qué es lo que construyen; no tanto indagar qué "son" sino qué "hacen".

Hablar de "lo social", y no de sociedad, permite evitar la idea tan arraigada en la imaginación arqueológica de que primero existe la sociedad conformada y luego la cultura material como producto de ella. Los individuos en sociedad son quienes crean los objetos, pero también es cierto que los objetos 


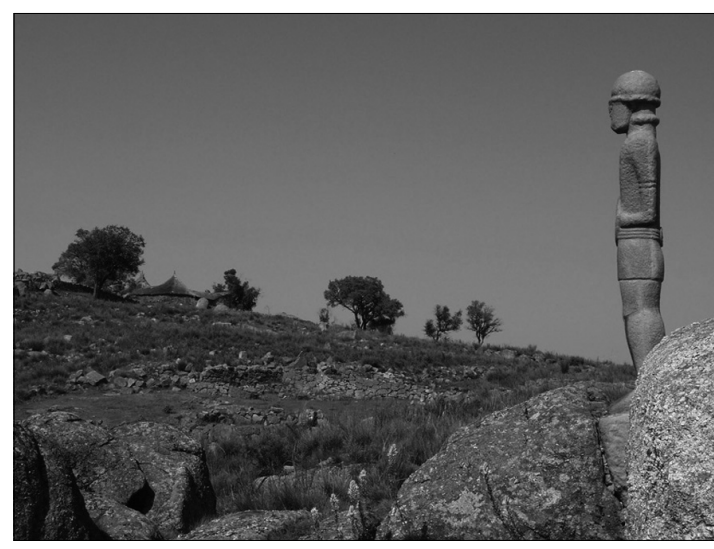

Figura 4. Réplica del guerrero de Sanfins encastrado en la roca (foto: Manuel Gago).

crean en gran medida las condiciones de posibilidad de esa sociedad. Lo social no es algo abstracto, sino que toma cuerpo a través de las formas materiales y las prácticas humanas. Los procesos de acción humana sobre las cosas materiales producen tipos de personas, y externalizan cultura que puede actuar como una fuerza autónoma que participa en las acciones, elecciones y comprensiones humanas (Miller 2005). Debemos ver la materialidad del castro, por tanto, como aquello que educa, impone o invita en silencio a estar en el mundo de un modo concreto y, por tanto, que da forma a lo social. Pero también, a través de la cual se configuran contextos teatrales altamente significativos y emocionales (Inimata y Coben 2006). La idea moderna de lazo social, o de contrato social adquirido a través del lenguaje por los individuos, ha contribuido poderosamente a ver las formas materiales como una consecuencia y no como una causa. Sin embargo, lo social no es lo que mantiene unido a una comunidad sino lo que es mantenido a través de las formas materiales. Los objetos y las formas materiales de un castro - entre los que se incluyen los guerreros de piedra- disponen de un papel activo en la producción y reproducción de las sociedades y las relaciones sociales. Como ha señalado Gombrich "es difícil encontrar una palabra para describir la capacidad que poseen las imágenes en tres dimensiones para introducirse en el mundo de los vivos, para convertirse no en una representación de algo sino en individuos de propio derecho" (1999: 139). Más que representaciones o portadores de, son actores, o si se quiere, actantes: agentes no humanos que "hacen hacer" (Latour 2001). Si asumimos por tanto una aproximación performativa y sinestésica de la materialidad, debemos ver las imágenes de guerreros más que representando aspectos de la so-

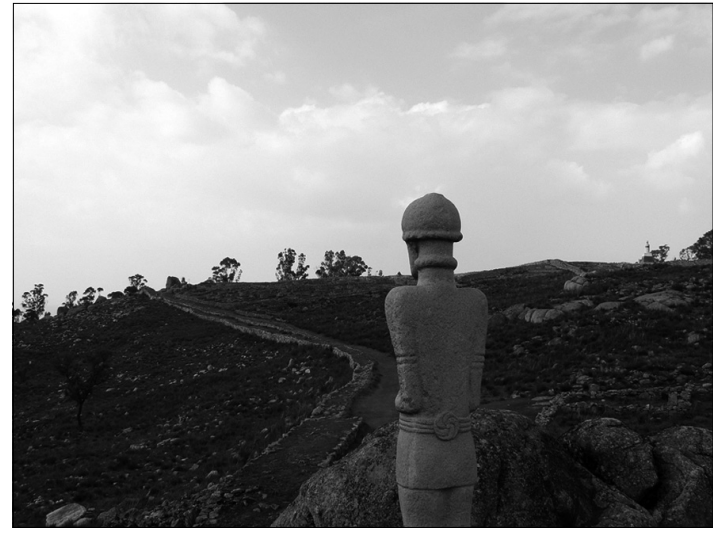

Figura 5. Réplica del guerrero de Sanfins en relación a la muralla. (foto: Sole Felloza).

ciedad, construyendo la sociabilidad indígena insertos en el colectivo material y humano del castro.

Una de las dificultades de interpretar imágenes del pasado es que, debido a que aparentemente sólo representan a algo o a alguien, son tratadas de modo diferente que al resto de artefactos, y por tanto no se les aplican criterios arqueológicos para estudiar su sentido. Pero, si nos aproximamos a las imágenes como artefactos, como objetos funcionales, el contexto cognitivo y arqueológico puede contribuir considerablemente a la interpretación de sus significados (Hamilton 1996: 282). De este modo, si queremos conocer algo más de ellas, saber cómo funcionan más qué lo que representan, debemos volver a ubicar estas estatuas en su contexto primario y reconstruir el teatro en el que desempeñaron activamente su papel (Figs. 4 y 5).

Los restos de estatuaria localizados entre las murallas o en las laderas de los castros - Roriz (Braga), Santa Comba y Bergazo (Lugo)—, pero sobre todo, como ya adelanté antes, la peana de la estatua encontrada in situ en Sanfins revela que estas imágenes se ubicaban en el contexto de las murallas y presidian las entradas de los castros. Además, la ubicación de esta peana muestra que al menos parte de estas imágenes se fijaban a las rocas que afloran en los castros (Figs. 4-5). A la luz de este hallazgo, cobra especial relevancia la afirmación que un vecino del monte del Senhor dos Perdidos trasmite a Sarmento cuando este le interroga sobre el guerrero de S. Jorge de Vizela: "es ahí [...] en la grieta de unas rocas donde aparecen los ídolos" (Sarmento 1999: 313). Parece posible que las piezas de Berganzo, Cendufe y Monte Mozinho, con peanas cónicas como las de Sanfins, tuvieran esta ubicación. El encaje de las imágenes de guerrero en las peñas, como ha se- 
ñalado Schattner, debió crear la sensación de que "las estatuas, en cierto modo, brotaban de la roca, del propio paisaje" (2004: 37). A pesar de que el color del granito de los castros actualmente nos trasmita una imagen en blanco y negro, las estatuas y las piedras decoradas de los castros pudieron estar pintadas como las paredes de algunas cabañas en los castros de Troña, Âncora, Monte Mozinho o S. Lorenço (Calo 1994: 798; Pena 2001). De ser así, su color y brillo debieron contribuir a su poder actante en el contexto del castro.

Una vez ubicadas las estatuas en la posición que ocuparon originalmente en el castro, debemos prestar atención a tres cuestiones: (a) la relación de estas imágenes con las formas materiales circundantes, las murallas y puertas; (b) la configuración performativa o teatral que su ubicación permite, creando un tipo de audiencia muy particular; y (c) los objetos y gestos iconográficos materializados en la imagen del guerrero que entran en acción en este teatro.

Las murallas y las entradas al recinto son espacios liminales, y por tanto una "zona situada entre poderosos sistemas de significado" (Turner 1967: 93). Un lugar en el que median dos espacios ontológicamente diferenciados y se concentra una gran cantidad de significados (Parker Pearson y Richards 1997). Las murallas se convierten en un "espacio de ansiedad" para la comunidad, especialmente notable en sus puntos de ruptura (vanos, entradas), objetoespacios transicionales que materializan lo que $\mathrm{Ba}$ chelard ha llamado "todo un cosmos de lo entreabierto" (Bachelard 1994: 222). A partir de la segunda Edad del Hierro, estos espacios se monumentalizan. Las grandes murallas trastocan el sistema perceptivo de estas comunidades potenciando las metáforas materiales de posesión y compartimentación del espacio. El poblado intramuros queda visualmente oculto del exterior, y se configura una topografía que objetiva una comprensión concreta del mundo de afuera, del que a su vez protege. Es desde el castro desde donde se piensa el mundo; es un espacio cognitivo y vivencial el que da sentido a un modo concreto de poetizar, construir, segmentar y transitar el paisaje, de estar-en-el-mundo. Así, los elementos materiales que construyen arquitectónicamente este espacio colectivo de habitación se convierten en lugares necesitados de la práctica del ritual.

La documentación arqueológica sustenta esta idea de modo reiterado a través de la documentación de depósitos humanos, de animales y metálicos documentados en relación a las murallas desde los primeros momentos (González-Ruibal 2006-2007; Rodríguez-Corral 2009: 178-180; Alfayé y Rodrí-
guez-Corral 2009; Alfayé 2007; 2009: 288-294). En relación a los depósitos humanos tenemos ejemplos como la cista con fragmentos craneales en la muralla de la acrópolis junto la puerta de Chao Sammartín (Grande de Salime) (viII a.C.) (Villa 2003); una mandíbula hallada en una capa de cenizas situada directamente sobre un nivel del siglo VI-v a.C. de la muralla de La Campa Torres, en Gijón (Asturias); así como inhumaciones infantiles en dos sectores de la misma muralla, que sus excavadores (Maya y Cuesta 2001: 295) relacionan con prácticas rituales de carácter liminal. Hay que añadir posibles cremaciones humanas relacionadas con murallas, en los poblados de Castromao (Celanova) (García Rollán 2004: 10), San Millán (Cualedro) (Rodríguez y Fariña 1986: 62) y Baroña (A Coruña) (Calo y Soeiro 1986: 35), que del mismo modo podrían corresponder a prácticas rituales ligadas a la protección mágica de la muralla, al igual que se documenta en asentamientos celtibéricos y galos (Alfayé 2007). En segundo lugar, como en otros contextos de la Europa templada, diferentes referencias orales aluden al hallazgo de huesos animales en el interior de paramentos castreños, información confirmada por el descubrimiento reciente de huesos de caballo dentro de la muralla del castro de Espiñaredo, en As Pontes (cf. González-Ruibal 2006-2007: 569). Asimismo, los dos depósitos de objetos metálicos asociados a las murallas del castro de Saceda (Cualedro) podrían tener un carácter ritual dadas sus similitudes espaciales y morfológicas con otros depósitos metálicos del norte de Europa (Hingley 2006), y estar destinados a dotar de protección sobrenatural a los paramentos.

Es en la zona de acceso donde las cabezas humanas labradas en piedra encuentran su lugar en los castros. Su representación en diferentes soportes y materiales constituye uno de los motivos más repetidos en el arte de la Europa templada y poseen una amplia cronología (Rosaldo 1980; Megaw 2003). Aunque cinco ejemplares han aparecido en el trascurso de excavaciones en castros, su datación es problemática, manejándose una cronología entre el i a.C. (González-Ruibal 2007: 135) y el I d.C. (Calo 1994: 720). En el Castro de Barán, dos piezas fueron halladas en una zona de piedras en la parte central del poblado (Álvarez Núñez 1993); en Monte Mozinho, una cabeza apareció junto a unas peñas con pilas (Calo 1994: 347 y 704); y en San Cibrán de Las (Orense), junto a la puerta de la muralla acropolitana, se localizó un bloque granítico en el que estaba tallada una cabeza (Calo 1994: 440). Con todo, es el hallazgo de la testa del castro de A Graña (Me- 


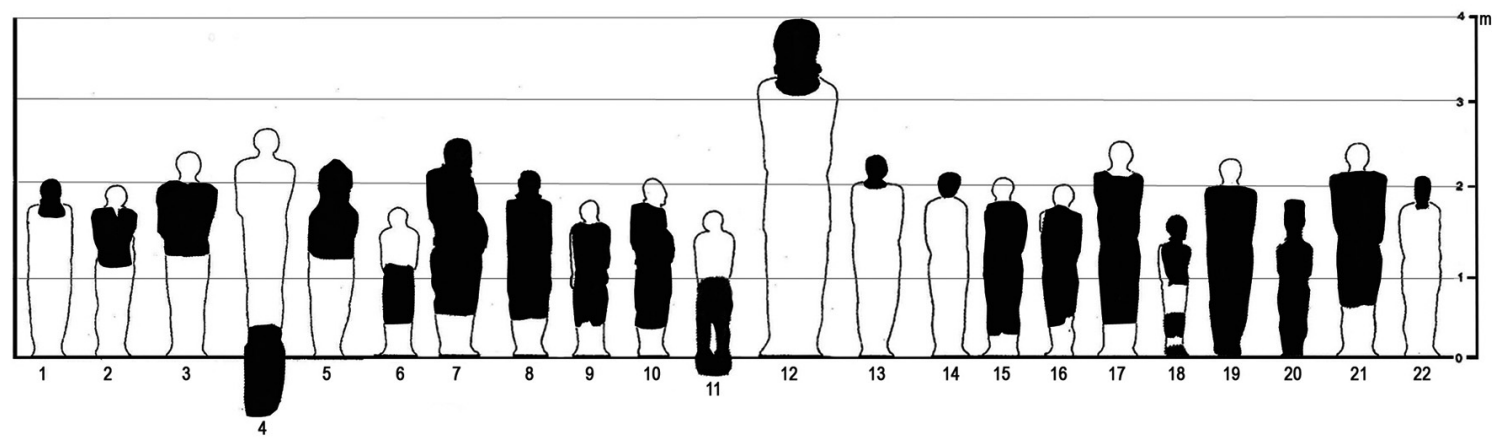

Figura 6. Comparativa de las dimensiones de las estatuas. 1. Anlló (Cea, Orense); 2. Armeá I (Allariz, Orense); 3. Armeá II (Allariz, Orense); 4. Bergazo (O corgo, Lugo); 5. Capeludos, (Vila Pouca de Aguiar, Vila Real); 6. Cendufe (Arcos de Valdevez, Viana do Castela); 7. Lezenho I (Boticas, Vila Real); 8. Lezenho II (Boticas, Vila Real); 9. Lezenho III o Campos I (Boticas, Vila Real); 10. Lezenho IV o Campos II (Boticas, Vila Real); 11. Monte Mozinho (Penafiel, Porto); 12. Ralle (Taboada, Lugo); 13. Río (Vilamarín, Orense); 14. Roriz (Barcelos, Braga); 15. San Jorge de Vizela (Filgueiras, Porto); 16. São Julião (Vila Verde, Braga); 17. San Paio de Meixedo (Viana do Castelo); 18. Sanfins (Paços de Ferreira, Porto); 19. Santa Comba I (Cabeceira de Bastos, Braga); 20. Santa Comba II (Cabeceira de Bastos, Braga); 21. Santo Ovídio de Fafe (Fafe, Braga); 22. Vilarelhos (Alfándega da Fe, Bragança) (a partir de Schattner, 2004: Fig. 9).

lide, A Coruña) el que ofrece una ubicación más clara con una entrada. Esta apareció en el extremo interior del corredor labrado en la roca que da acceso al poblado, por lo que debió de estar situada encima de la puerta o empotrada en alguna de las torres (Calo 1994; Barciela y Rey 2000: 135-136). Interpretadas como rostros de difuntos, divinidades o cabezas cortadas al enemigo, podrían funcionar como entidades tutelares o imágenes apotropaicas en el contexto de las entradas a los recintos.

De este modo, si los iconos de guerreros se sitúan en relación a las murallas y las puertas, en un espacio de especial relevancia liminal, cabe preguntarse cuál es su audiencia. Podríamos destacar tres características del observador de estas imágenes: en primer lugar, se encuentra fuera del castro; en segundo lugar, se acerca al castro en dirección a la puerta, al punto más crítico, en donde, en tanto se pasa de un espacio ontológico a otro, se vuelve un espacio de ansiedad; y en tercer lugar, este observador contempla en movimiento la estatua, es decir, cambia de posición o punto de vista, se acerca a ella desde lejos. Frente al movimiento del observador, la lógica material, el hieratismo y la simbología subrayan la posición estática del guerrero. Es aquí donde la envergadura de esta estatuaria debe ser tenida en cuenta. La mayoría de estas imágenes superan los dos metros de altura, y si atendemos a los 85 centímetros que mide la cabeza de Ralle, podríamos estar ante estatuas que pudieron haber alcanzado en algún caso los cuatro metros de altura (Fig. 6) (Fernández Carballo 2001; Calo 2003: 15; Schattner 2004: 40). El tamaño no natural acrecentaría su poder actante en el contexto liminal: en primer lugar porque permite que las personas que se dirigen hacia la entrada del castro puedan contemplarlo mientras se aproximan; y en segundo lugar, porque una vez se hallen frente a la imagen, su tamaño, como ha señalado GonzálezRuibal (2006-2007: 439), enfatizaría los valores y el poder del guerrero.

El acto de acceso a un asentamiento en la antigüedad se vincula a dos instituciones: la hospitalidad y la guerra. La hospitalidad o el hospitium en el mundo antiguo es problemático. El propio término latino hospitium comparte la raíz latina con hospes (el extranjero) y hostis (el enemigo). Se hace necesario por tanto de una institución, una transición que rompa con el círculo cerrado del castro capaz de establecer relaciones de sociabilidad entre los miembros de la comunidad y los acogidos en ella (hospites) (Salinas 2006: 121-122). En relación a este espacio de tránsito y ansiedad, probablemente están conectados determinados depósitos documentados en el exterior de las murallas de castros como los de Sofán y Castelo de Neiva. En el primer caso, se localizaron en el exterior del asentamiento un conjunto de puñales (López Cuevillas 1989); y en el segundo caso, en la parte más baja de la ladera del oppidum se encontraron dos cascos montefortinos de bronce decorados - metido uno dentro del otro- y, a medio metro de distancia, tres copas de bronce y los restos de dos sítulas (Almeida 1980). Asimismo, depósitos de pequeños objetos como cuentas de collar en la puerta de entrada de castros como el de Saceda (González-Ruibal 2005: 277) podrían remitir a ritos cotidianos de paso. 


\section{ICONOGRAFÍA Y ESTÉTICA}

¿Qué le está diciendo entonces la materialidad del guerrero castreño a una audiencia que se acerca a ese espacio de ansiedad? En el contexto de creciente inestabilidad, jerarquización y confrontación que tiene lugar desde finales del siglo II a.C. con la entrada de Roma en la escena del noroeste peninsular, las imágenes pueden ser una poderosa arma - consiguen reforzar ideas e identidades, funcionar como eficaces mecanismos de resistencia, sublimar aspectos de la realidad-, y a través de su performatividad, estética e iconografía contribuir activamente a la construcción de la sociabilidad del castro.

Diversos autores (Almeida 1974; Calo 1994; Schattner 2004) han señalado la existencia de pequeños contrastes por ejemplo en el grado de naturalismo o movimiento entre las estatuas de guerreros. En mi opinión el mayor naturalismo en algunos de los iconos no debe ser considerado como algo que es buscado conscientemente; del mismo modo que su ausencia tampoco debe achacarse a una incapacidad en la ejecución. Las causas de esas diferencias pueden responder a cuestiones de diversa naturaleza - el lugar, el momento, y el artista-. Sin embargo, creo que no se puede sostener que las estatuas sean el producto de la incapacidad de imitar los modelos romanos bracarenses. Ni tampoco que la falta de control técnico del medio (la piedra) pueda suponer, como afirma Calo (1994: 803), que la plástica castreña — como producto final— no se corresponda con el ideal estético castreño perseguido. Si dentro del propio arte provincial romano, entender el provincialismo únicamente como un fracaso en la consecución del canon clásico, resulta problemático y oscurece las lógicas locales al margen de la metrópoli (Revell 2009; Hodos 2010; Hingley 2010), en el caso de una manifestación que surge en contacto con Roma, pero en un contexto aun sin romanizar, lo resulta aún más. Aunque una cabeza toscamente labrada como la de San Cibrán de Las pueda resultar imperfecta a los ojos de un observador educado en el canon clásico, no tiene que parecérselo a un observador que valore otras características como puede ser la funcionalidad de la pieza (Gell 1998).

De este modo, creo que no podemos pensar estas imágenes prerromanas basándonos en un rasgo propio del arte greco-romano como el naturalismo, ya que no tiene que formar parte de la lógica, estética, función e intención de una tradición escultórica como la castreña. Hacerlo supone asumir un metarrelato evolutivo, que teleológicamente sitúa la estética romana como ideal universal, y que marca fases y rasgos por lo que un arte tiene que pasar para madurar. Debemos asumir simplemente que nos encontramos ante iconografías alternativas que construyen sociabilidades distintas. Como ha argumentado Noelke (2003), la plástica puede ser un espacio de resistencia y negociación en contextos de romanización. Si en este ambiente, el incumplimiento de los cánones clásicos puede constituir un signo de resistencia a las normas de representación del poder imperial, y no solo un reflejo de una romanización parcial o inacabada (Aldhouse-Green 2003), de modo más evidente podrá suceder en un contexto de transformaciones, contacto, negociación y enfrentamiento, previo al control efectivo del poder imperial romano sobre de la región.

En mi opinión, las imágenes de guerreros son un ejemplo de resistencia e independencia, sublimada en el arte, entendido este como "una tecnología especializada para lograr efectos específicos" (Gell 1998). La propia estética de los guerreros que se aleja del naturalismo romano hacia un hieratismo puede trabajar en esta dirección, al mismo tiempo que trabaja en la construcción de la identidad castreña. La materialidad, a través de una serie de características como la solidez, la fijeza y el tamaño, puede resultar, como ya señalamos, crucial en la construcción significativa y performativa de la imagen. Pero igualmente, el canon estético puede evocar una poderosa realidad social. La simplificación del cuerpo es un poderoso acto de concentración. Al presentar una imagen minimalista y estandarizada del guerrero se crea una imagen esencial y reguladora que quiere influir de un único modo. Lo que la imagen pierde en naturalismo o movimiento, lo gana en inmediatez y compresibilidad (Robb 2009: 174), cediendo todo el protagonismo a la iconografía - las armas, los gestos y los motivos simbólicos-, clave para la eficacia de la propia imagen en el espacio teatral que acabamos de describir.

\subsection{El ESCUDO Y SU VALOR SIMBÓlico}

La performatividad del armamento de la escultura actúa en la construcción y defensa de estas comunidades, siendo una de sus características más llamativas la posición del escudo o caetra (Fig. 7): el guerrero lo sujeta frontalmente a la altura del vientre, mostrándolo al visitante que se acerca a la zona de entrada al castro. Esta posición tan forzada puede estar relacionada con su papel simbólico en el mundo antiguo (Quesada 2003): la posesión del escudo señala la independencia y anuncia la defensa de la 

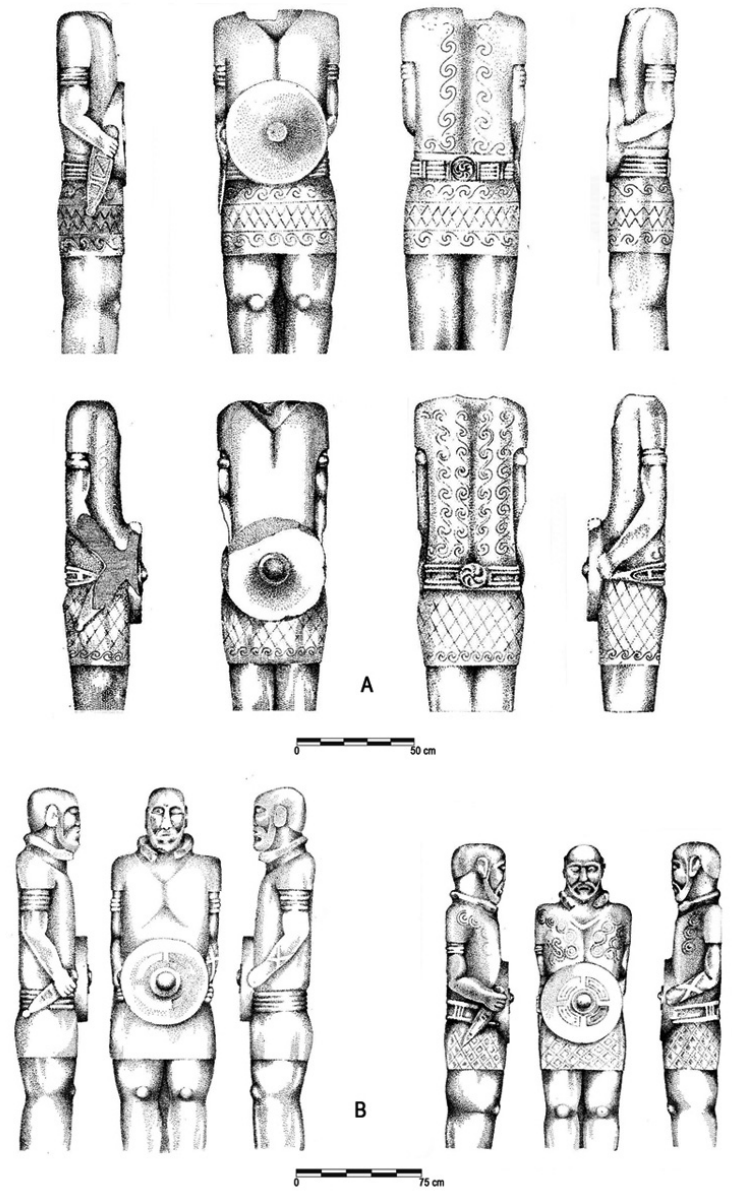

Figura 7. Estatuas de guerreros decorados (a partir de Silva, 1986): A. Campos; B. Lezenho.

misma, y funciona como una metáfora material de protección. Su pérdida, como ha señalado Lincoln (1991: 143) implica la renuncia del grupo vencido a los límites sociales que previamente había mantenido, lo que responde a una concepción del escudo como frontera móvil que separa a uno mismo, al grupo y al territorio, del Otro.

Más complicado resulta interpretar el significado de la figura geométrica que se representa en los escudos de cinco de los iconos castreños — los ejemplares de Cendufe, de Armeá, de San Jorge de Vizela y los dos de Lezenho-. Si asumimos la interpretación tradicional que ve en él un laberinto, cabe pensar, como ha señalado Quesada (2003), que tal motivo podría ahondar en esta dimensión apotropaica del guerrero. El laberinto, entre sus múltiples significados, está vinculado con la defensa física de un territorio o asentamiento a través de su protección mágicoreligiosa (Gell 1998). Sin embargo, debemos notar que lo que se representa en los escudos no es un laberinto strictu sensu. El dibujo geométrico, que también figura en las monedas de la caetra y que vuelve a aparecer en una metopa de Porta Flaminia (Blanco 1971), podría ser un motivo característico de la segunda mitad del siglo i a.C. Como ha señalado Höck (2003: 56) "si el motivo es tan típico para el noroeste, y la pieza descubierta por Blanco en la capital del imperio tan única, [...] sería lógico pensar que los romanos hubieran tomado por modelo un motivo preexistente entre los indígenas del noroeste", o por lo menos surgido en el contexto del noroeste.

Es posible que el motivo representado en los escudos de los guerreros remita a una simbología del centro o esté plasmando la planta ideal de un asentamiento de ese momento. De hecho, podrían estar referenciando las dos cosas a la vez. El concepto centro-periferia (unidad-multiplicidad) constituye una de las bases fundamentales del simbolismo arquitectónico (Rykwert 1985; Snodgrass 1992: 21-24; Robinson 2003). Además, no debemos obviar que en otros contextos se han documentado grabados en piedra que perecen ser representaciones esquemáticas de plantas de asentamientos como hillforts (Myberg 2006) o de estructuras arquitectónicas como cairns (Bradley 2009: 42-43).

Las plantas de asentamientos como Monte Mozinho o San Cibrán de Las, en pleno funcionamiento en la segunda mitad del siglo i a.C., muestran un curioso parecido con los motivos representados en el escudo. Ambos castros muestran un recinto de carácter ritual en la zona central, alrededor del cual se construye el caserío formando un anillo a su alrededor. En segundo lugar, en el caso de San Cibrán de Las, se ha demostrado una estricta planificación de su planta: primero se marcó la trama del castro y se delimitaron las parcelas, para luego edificar en ellas. Así "todas las viviendas se disponen en el recinto exterior, alrededor de calles radiales que se comunican con la rolda inferior y la superior a modo de ejes circulares" (Álvarez González 2007: 30) tal como aparece representado en el motivo. En tercer lugar, estos castros se construyeron en el marco de un proceso de sinecismo característico del siglo i a.C. (González-Ruibal 2006-2007: 338-348), siendo concebidos "desde su origen para albergar un gran número de personas y la superficie interior fue dividida en parcelas similares para cada familia" (Álvarez González 2007: 31). Alrededor de la acrópolis amurallada debió entrar a vivir gente de diferentes lugares, probablemente concentrándose por criterios de filiación en zonas o barrios del castro. Esta pluralidad poblacional encontraría su punto de unidad en el recinto 
central amurallado, un espacio sagrado no habitado, en el que se documentan diversas inscripciones votivas y en el que en una de sus entradas se ha encontrado el relieve de una cabeza. Dos movimientos radiales se permiten en el dibujo y en la planta del castro: desde el centro a la circunferencia y desde la circunferencia al centro. Lo interno avanza hacia lo externo y lo externo hacia lo interno. Desde la unidad hacia la multiplicidad y de esta a la unidad.

Las cinco imágenes de guerreros que llevan en el escudo este motivo geométrico podrían remitir a momentos finales del siglo i a.C., y la representación de este símbolo, junto a las armas, en las monedas de caetra, podría señalar la nueva realidad. De este modo, la figura geométrica de la caetra, al aparecer en el escudo, señalaría lo que este protege, potenciando el poder del icono como elemento protector del asentamiento. En San Cibran de Las todavía no se han encontrado estatuas de guerreros, mientras que en Monte Mozinho aparecieron restos de dos ejemplares en la propia excavación, conservándose únicamente el tronco de uno de ellos. Sintomáticamente, a esta estatua le fue arrancado el escudo, lo que podría estar indicando la importancia de este símbolo, y remitiendo tal vez a prácticas de desactivación o a actitudes iconoclastas (Fig. 8).
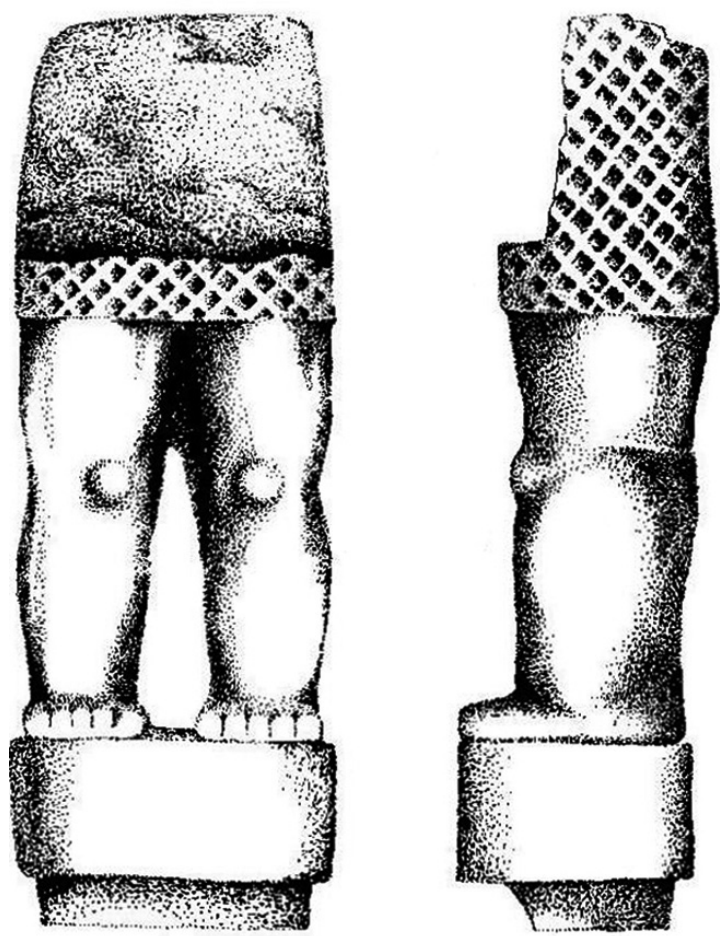

Figura 8. Escultura de guerrero de Monte Mozinho (a partir de Silva, 1986).
El hecho es que esta estatua, como ha señalado Almeida (1974: 28) y Calo (1994: 345), es prácticamente igual al ejemplar de Cendufe en el que aparece el motivo geométrico. Con todo, no contamos con argumentos más sólidos que los aquí esgrimidos para sostener tal interpretación, por lo que simplemente debe considerarse una hipótesis más de una representación geométrica de difícil exégesis.

\subsection{LAS DIESTRAS: SIGNIFICADO, MATERIALIDAD Y PRAXIS}

La mano derecha posee una gran significación en la sociabilidad indígena ya que a través de ella se representan los gestos y actos materiales más importantes de estas comunidades. La diestra canaliza la paz y la guerra. Por un lado, sirve para estrecharla con otro individuo ya se trate de un acto individual o que atañe a un grupo o a la comunidad. Con ella se realiza el gesto material de la fides. Por otro lado, la mano derecha canaliza la guerra. Portadora de la espada, es portadora de la violencia y de la capacidad que el individuo tiene - - y por extensión la comunidad - para defenderse y someter al otro. Ambos aspectos hacen de las diestras una metáfora material sobre la que actuar y con la que actuar en la negociación de la realidad de estas comunidades.

Los textos clásicos, la iconografía y el registro arqueológico en relación a las sociedades prerromanas de la península Ibérica dan fe de ello. Estas comunidades contaban con un corpus gestual para consignar la hospitalidad y la fides. Tal vez el ejemplo material más claro de las diestras estrechadas (dextrarum iunctio) como índice de la fides (Marco 2006) sea la adopción de esa forma por algunas téseras de hospitalidad halladas en la Península, de las que varias llevan texto escrito en lengua celtibérica. Es común que en las inscripciones de este tipo de téseras aparezca la palabra Car que, interpretada según autores como abreviatura de caruo o como nominativo femenino de tema en $r$, o bien remite a la idea de pacto de hospitalidad o bien es el equivalente indígena de hospitium (Peralta 2000: 143144).

Del mismo modo, la mano derecha es la que porta el arma y, por tanto, su simbolismo material y metafórico se vuelve de gran relevancia en la sociabilidad indígena. A través de Estrabón $(3,3,6)$ sabemos que las comunidades indígenas del noroeste cortaban "las manos de los prisioneros y consagraban las diestras". Se trata de una acción muy extendida entre las comunidades indígenas de la península 


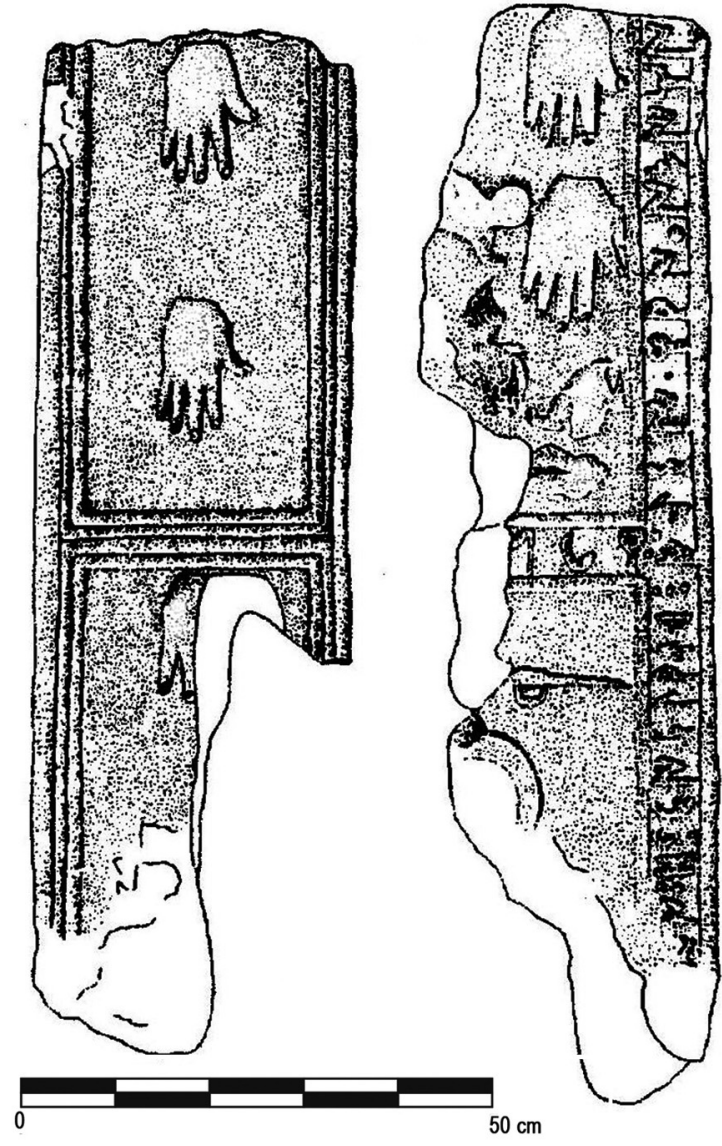

Figura 9. Estela de La Vispesa (Tamarite de Litera, Huesca). Siglos II-I a.C. (Marco y Baldellou, 1976).

Ibérica durante la Edad del Hierro. La práctica de amputar la mano al enemigo no sólo busca su humillación sino que, como señala Sexto Aurelio Victor (De Vir. III, 58), también forma parte de las pruebas de valor. Este autor narra como un padre para decidir el futuro marido de su hija pone como prueba a sus pretendientes salir del poblado de Numancia y volver con la mano diestra de alguno de algún enemigo. Diodoro Sículo $(12,56,5)$ nos cuenta como en la batalla de Selinunte en el 409 a.C. mercenarios procedentes de Iberia llevaban manojos de diestras atadas en el cinturón, y las cabezas del enemigo clavadas en las lanzas. De hecho, Roma adoptó esta medida de los pueblos prerromanos de la Península como método para castigarlos y someterlos. Por ejemplo, Valerio Maximo $(2,17,11)$ relata cómo desde las guarniciones militares de Serviliano se ordenó amputar las diestras a los lusitanos que abrazaron la causa de Viriato.

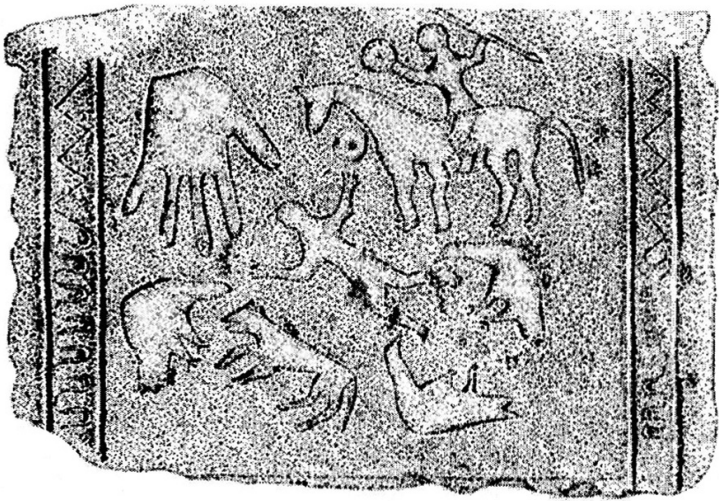

Figura 10. Estela de El Palao (Alcañiz, Teruel). Siglos II-I a.C. (Marco, 1976).

La iconografía suministra dos ejemplos del gran valor simbólico de las diestras y el escudo en el contexto de las poblaciones indígenas de la península Ibérica, analizados recientemente por Alfayé (2004). En la estela de La Vispesa (Tamarite de Litera) (II-I a.C.) (Fig. 9) se representan las diestras, la caetra y la lanza del vencido. Más arriba se representan los dos cadáveres mutilados que sufren una amputación selectiva de la diestra y la cabeza, y un buitre que se lanza en picado hacia ellos. En el segundo caso, la estela del Palao en Alcañiz (II-I a.C.) (Fig. 10), se narra un acto vejatorio y deshonroso de negación de sepultura a un enemigo por parte del guerrero victorioso. El jinete porta lanza y caetra mientras al pie del équido un cadáver es devorado por alimañas. Una vez más aparece representada la amputación de la mano diestra y la pérdida del escudo. Igualmente, Marco (1998: 393-394) ha interpretado parte de la iconografía de la lúnula de Chão de Lamas (Conimbriga) como una escena de degradación y de amputación de las extremidades.

Estas prácticas han sido igualmente confirmadas por el registro arqueológico en el asentamiento de la Edad del Hierro de La Hoya (Laguardia, Álava). En torno al siglo III a.C. el poblado es asediado e incendiado, y sus habitantes asesinados. Los restos óseos permiten comprobar que la gente del poblado fue sometida a prácticas de mutilación, entre las que se documenta la amputación de las diestras y la cabeza (AA.VV. 1992; Llanos 2005; 2007-2008). En suma, parece evidente que la privación por vía violenta de estos miembros adquiere la consideración de una sinécdoque (Sopeña 2009): la diestra como significante de la capacidad social de los individuos los inutiliza como tal si ésta les es amputada. 


\section{IMÁGENES EN ACCIÓN Y SIMBOLOGÍA FRACTAL}

Si asumimos la importancia del escudo al frente para crear un espacio diferenciado frente al enemigo/extranjero, y las diestras como metáforas materiales de la independencia y capacidad política y militar de los individuos, parece cobrar sentido que los guerreros castreños sobre las murallas adopten los dos gestos. La mano diestra siempre agarrando el puñal o espada corta - como ocurre en las estatuas de Lezanho, Meixedo, Santo Ovidio de Fafe y una de las de Santa Comba- o portando la espada desenvainada - en los casos del otro ejemplar de Santa Comba o en uno de los de Armeá-, permiten trabajar a estos guerreros de piedra como imágenes activas en la construcción y protección del espacio liminal.

Es en el conjunto performativo constituido por espacios ontológicamente diferenciados y sancionados por las murallas, las puertas, la práctica ritual, y las imágenes en acción dirigidas a un extranjero (en tanto su ubicación) y a un enemigo potencial, por su ubicación, en donde debemos encontrar las condiciones de posibilidad del significado de estos guerreros, que crean la frontera del grupo como agentes apotropaicos. No es un simple reflejo de una ideología heroica, sino que se trata de un artefacto activo. Su performatividad emana de la incardinación del soporte (piedra), de la acción materializada en él (mostración del escudo y la diestra armada), del lugar en el que la imagen se exhibe (la muralla), y de la audiencia para la que está destinada (los individuos que acceden al recinto desde el exterior), produciendo a nivel pre-predicativo la liminalidad del espacio y activando el poder de la imagen. Así, el significado de la muralla como espacio liminal en la arquitectura del castro es enfatizado por la presencia del guerrero de piedra, que anuncia visualmente y con antelación esta zona de transición, marcando la independencia del castro y funcionando a su vez como activo elemento protector de la comunidad.

A este colectivo de formas materiales - murallas, puertas, guerreros y prácticas rituales - hay que añadir por último las saunas castreñas y las piedras con decoración que adornaban dinteles, jambas y cornisas de las casas. Sabemos que las saunas del área lucense se remontan al menos hasta el siglo IV a.C., y que las del área bracarense están funcionando durante la segunda Edad del Hierro (Villa 2002; 2007; Queiroga 2003; Armada 2001). Por otra parte, diversos contextos arqueológicos sitúan en un horizonte prerromano a las piedras con simbología y decora- ción. En Cividade de Ancora tenemos hexasqueles datados a finales del siglo II y principios del siglo i a.C. -en todo caso, anteriores a Augusto- (Silva 1986: 63), y en Castromao, trisqueles que se datan en la primera mitad del siglo I a.C. (Coimbra 2009); esta plástica también se documenta en castros como Forca (Carballo 1996: 65) y Sabroso (Silva 1986: 31), abandonados antes de la romanización. Como ha señalado Carballo (1996), los motivos de la decoración plástica remiten sin duda a aquellos característicos de la cerámica prerromana (Rey 1996).

Las saunas son contextos igualmente liminales: en primer lugar, por su ubicación topográfica (se sitúan en relación a las murallas y las puertas); en segundo lugar, por su propia arquitectura (a través de un sistema semi-hipogeo con divisiones físicas y materiales que crean cambios sinestésicos en las personas); y en tercer lugar, porque en ella se representan —al igual que en las imágenes de guerreros, y en los muros y vanos de las casas - motivos simbólicos (trisqueles esvásticas, cordados, etc.) que redundan en esta liminalidad, y que parece que nos remite a una concepción fractal del espacio del castro (Fowler 2008).

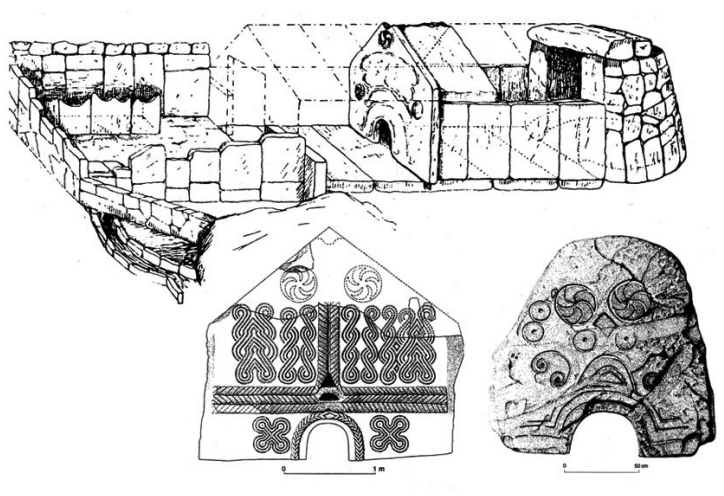

Figura 11. Sauna castreña y pedras formosas decoradas (a partir de Cardozo, 1932 y Queiroga, 2003).

Por un lado, estos símbolos materiales representados en objetos reales como torques o diademas, aparecen también en el cinturón de las estatuas, relacionados por algún autor con los cinturones mágicos de fenicios y púnicos en contacto con el noroeste a través de las relaciones de intercambio atlánticas (González-Ruibal 2004: 119). En el segundo lugar, aparecen como un rasgo característico y diferenciador en los muros y los vanos de las casas. Ya sea empotrado en los propios muros o a través de trisqueles calados como los de Castromao. El uso protector y social de estos símbolos contra la polución (Gell 
1998), característico de muy diversos contextos, parece ser el desempeñado en los espacios domésticos castreños (Vesconcelos 1913: 80; Lopéz Cuevillas 1989; González-Ruibal 2004; 2006-2007; RodríguezCorral 2009; Coimbra 2009). Y en tercer lugar, en las pedras formosas sancionan la práctica ritual dentro de la sauna creando dos espacios bien diferenciados fenomenológica y simbólicamente (Fig. 11). El movimiento dentro de la sauna supone en sí mismo una transformación sinestésica. Sensaciones corporales que exigen un tipo de movimiento muy concreto como introducirse a través del pequeño vano de la pedra formosa- y que llevan al individuo desde la luz a la oscuridad, de lo frio a lo caliente, de lo seco a lo húmedo o viceversa; e incluso cambios a nivel olfativo (el sudor y las grasas) y a nivel auditivo (resonancias internas) (González-Ruibal 2006-2007: 575; Rodríguez-Corral 2009: 189-193). Ya esté la pedra formosa dividiendo y creando espacios de privación, alteración, o creación sensorial —debates similares para cuevas, monumentos megalíticos o templos malteses, han sido planteados en los trabajos de LewisWilliams (2003) y Tilley (2007; 2008)—, los símbolos materiales aparecen justo ahí, en ese momento liminal donde el ambiente sinestésico del individuo muta y se transfigura.

Otros motivos, como sogueados o SS concatenadas, igualmente decoran la vestimenta de las estatuas de guerreros, las paredes, dinteles y jambas de las casas y las pedras formosas. La decoración funciona como un tipo de "tecnología del encantamiento" que hace que su eficacia social no se deba sólo a cuestiones de naturaleza simbólica sino también cognitiva. Este tipo de motivos no pueden ser considerados simples ornamentos, si entendemos estos como algo sin función. La decoración es esencial a la funcionalidad psicológica de los artefactos, de la vestimenta y de los elementos arquitectónicos y no puede ser disociada de sus otras funciones sociales y prácticas. Siguiendo a Gell (1998: 83-84), podemos plantear que el uso de patrones geométricos como los de la puerta de Cividade de Ancora pudieron servir como dispositivos de protección contra la polución (Gell 1998: 84) (Fig. 12).

De este modo, parece existir una estructura fractal de la simbología que construye la sociabilidad indígena del castro. El cuerpo, la casa, el poblado y la pedra formosa muestran una simbología y unos ornamentos comunes en sus superficies liminales. Si partimos de una concepción fractal del espacio material y social del castro, cabe pensar que todos los símbolos y decoraciones funcionarían al mismo tiempo en la construcción social, sinestésica y cognitiva

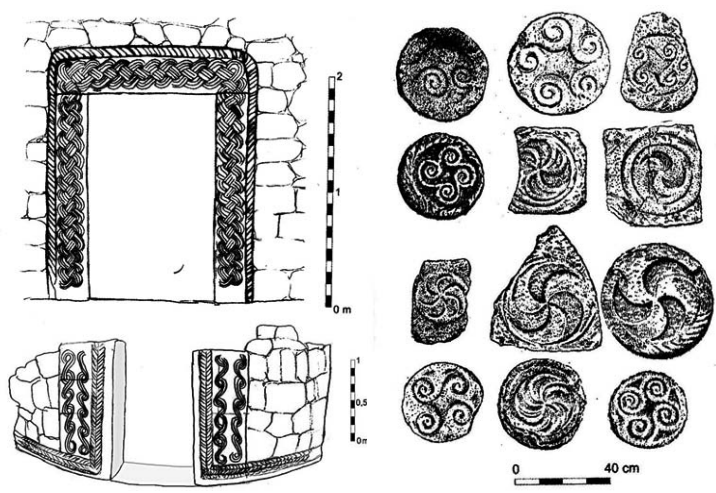

Figura 12. Decoración y motivos simbólicos en la arquitectura doméstica (a partir de González-Ruibal, 2004).

de lo que es ser castreño, un modo de ser-en-el-mundo previo a la romanización que estaría funcionando con seguridad desde finales del siglo II a.C. y que a partir del cambio de era paulatinamente se fue desactivando.

En el siglo I d.C., en castros como Santa Tecla o Cividade de Ancora, esta decoración plástica se amortiza como material de construcción, o queda oculta por nuevas construcciones, lo que indica por tanto que pierde su valor cognitivo y simbólico y su función apotropaica. Es lógico pensar que si estos símbolos pierden su sentido y función en las paredes de las casas, del mismo modo dejarán de funcionar en los cinturones de los guerreros castreños y en las pedras formosas. Las murallas dejan de repararse, el espacio intramuros se abandona o va perdiendo población, y el caserío se extiende ahora fuera de las murallas como se constata en Castromao o Monte Mozinho. El espacio performativo y fractal que acabamos de reconstruir se desmantela y las estatuas empiezan a perder su papel. Los iconos guerreros se desactivan, y en algunos casos, en torno a mediados del siglo I d.C. reciclan sus significados y usos. Insertos ya en otros colectivos materiales, negocian otras realidades que se añaden como una fase más a su biografía cultural. Será ahora cuando sobre algunas estatuas se añada un epígrafe. Sabemos que el guerrero de São Julião se encontró en la escombrera antigua de una excavación de niveles de ocupación romana del castro, lo que nos señala el contexto secundario en el cual la imagen y epígrafe convivieron. Es ahora, también, en la primera mitad del siglo I d.C., cuando el guerrero del Sanfins que se situaba en una de las entradas del castro, se desmantela y se reubica junto a dos aras anepígrafas en el interior de una estructura en lo alto del castro. 


\section{BIBLIOGRAFÍA}

AA.VV. 1992: La enfermedad en la Prehistoria de Álava, Vitoria.

Alarcão, J. 1988: O dominio romano en Portugal, Sintra.

Alarcão, J. 2003: “As estátuas de guerreiros galaicos como representaçôes de príncipes no contexto da organizaçâo político-administrativa do noroeste préflaviano", Madrider Mitteilungen 44, 67-86.

Aldhouse-Green, M. 2003: "Alternative iconographies. Metaphors of resistence in romano- british cult imagery", P. Noelke (ed.), Romanisation und Resistenz in Plastik, Architektur und Inschriften der Provincen des Imperium Romanum, Mainz am Rhein, 39- 48.

Aldhouse-Green, M. 2004: An archaeology of images. Iconology and cosmology in Iron Age and roman Europe, London.

Alfayé Villa, S. 2004: "Rituales de aniquilación del enemigo en la 'Estela de Binéfar' (Huesca)", Actas del XXVII Congreso Internacional Girea-Arys IX: Jerarquías religiosas y control social en el mundo antiguo, Valladolid, 63-74.

Alfayé Villa, S. 2007: "Rituales relacionados con murallas en el ámbito Celtibérico", Palaeohispanica 7, 9-41.

Alfayé Villa, S. 2009: Santuarios y rituales en la Hispania Céltica, Oxford.

Alfayé Villa, S. y Rodríguez-Corral, J. 2009: "Espacios liminales y prácticas rituales en el noroeste peninsular", Acta Palaeohispanica X, Palaeohispanica $9,107-111$.

Almagro-Gorbea, M. 2003: "La escultura en la Hispania céltica", Madrider Mitteilungen 44, 150-161.

Almagro-Gorbea, M. y Lorrio, A. J. 1989: "Representaciones humanas en el arte céltico de la península Ibérica", Actas II Symposium de Arqueología Soriana, Soria, 409-451.

Almeida, C. A. F. de 1974: Escavações no Monte Mozinho, Penafiel.

Almeida, C. A. F. de 1980: "Dois capacetes e tres copos en bronze de Castelo de Neiva", Gallaecia 6, 245-255.

Almeida, C. A. D. de 1981: "Nova estátua de guerreiro galaico-minhoto (Refojos de Basto)", Arqueologia 3, 111-116.

Almeida, C. A. F. de 1986: "Arte castreja. A sua lição para os fenómenos de assimilação e resistência a romanidade", Arqueologia 13, 161-172.

Álvarez González, Y. 2007: San Cibrán de Las. Guía de castros de Galicia e noroeste de Portugal, Santiago de Compostela, 30-31.
Álvarez Núñez, A. 1993: "Castro de Barán 91, Informe de la primera intervención Arqueológica", Boletín do Museo Municipal de Lugo 5, 153-178.

Álvarez Núñez, A. 1993-94: “Castro de Barán 92, Informe de la segunda intervención Arqueológica", Boletín do Museo Municipal de Lugo 6, 199223.

Álvarez-Sanchís, J. 1999: Los Vettones, Madrid.

Armada Pita, X. L. 2001: "Monumentos termáis castrexos: unha contribución á súa Interretación", Anuario Brigantino 24, 61-82.

Bachelard, G. 1994: La poética del espacio, México.

Barciela Garrido, P. y Rey Seara, E. 2000: Xacementos arqueolóxicos de Galicia. Guía práctica para visitar e coñecer o patrimonio arqueolóxico galego, Vigo.

Bettencourt, A. 2005: "A estatuaria”, J. M. Hidalgo Cuñarro (coord.), Arte e Cultura de Galicia e Norte de Portugal, Arqueoloxía 1, 166-177.

Blanco Freijeiro, A. 1971: "Monumentos romanos de la conquista de Galicia", Habis 2, 223-227.

Bradley, R. 2002: The past in prehistoric societies, London.

Bradley, R. 2009: Image and audience. Rethinking prehistoric Art, Oxford.

Calo Lourido, F. 1993: A cultura castrexa, Vigo.

Calo Lourido, F. 1993-94: "Arte castrexa: escultura e decoración arquitectónica", Cuadernos de Estudios Gallegos 41, 75-110.

Calo Lourido, F. 1994: A plástica da cultura castrexa galego-portuguesa, A Coruña.

Calo Lourido, F. 2003: "Catálogo", Madrider Mitteilungen 44, 6-32.

Calo Lourido, F. 2007: "Xesús Taboada Chivite, lindeiros e plástica da Cultura Castrexa", Boletín Auriense 37, 109-152.

Calo Lourido, F. 2010: Os celtas, una (re)visión dende Galicia, Vigo.

Calo Lourido, F. y Soeiro, T. 1986: Castro de Baroña. Campañas 1980/84, Arqueoloxía-Memorias, Santiago de Compostela.

Carballo Arceo, L. X. 1996: "Notas en torno a cronoloxía do Castro da Forca e da plástica Castrexa", Minius 5, 65-75.

Coimbra, F. A. 2009: "Trisceles, tetrasceles e motivos afins em elementos arquitectónicos Castrejos", Aquae Flaviae 41, 253-268.

Domanska, E. 2006: "The material presence of the past", History and Theory 45 (3), 337- 348.

Fernández Carballo, L. 2001: “O guerreiro galaico de Ralle (Taboada-Lugo): relectura etnoarqueolóxica do torques", Gallaecia 20, 133-147. 
Fernández Ochoa, C. y Zarzalejos Prieto, M. 1994: "La estela de Chillón (Ciudad Real). Algunas consideraciones acerca de la funcionalidad de las 'Estelas de Guerrero' del Bronce Final y su reutilizacion en época romana”, C. de la Casa (ed.), Actas del V Congreso Internacional de Estelas Funerarias, Soria, 263-272.

Fowler, C. 2008: "Fractal bodies in the past and present", D. Boric. and J. Robb (eds.), Past bodies. Body-centred research in Archaeology, Oxford, 47-58.

García Rollán, M. 1971: "Memoria de la excavación arqueológica de Castromao (Caeliobriga)", Archivo Español de Arqueología 44, 175-211.

García Rollán, M. 2004: "Hitos importantes en la excavación de Castromao (Caeliobriga)", Boletín Auriense 34, 9-14.

García Sanjuán, L., Garrido González, P. y Lozano Gómez, F. 2007: "Las piedras de la memoria (II). El uso en época romana de espacios y monumentos sagrados prehistóricos del sur de la península Ibérica", Complutum 18, 109-130.

García Sanjuán, L., Garrido González, P. y Lozano Gómez, F. 2008: "The use of prehistoric ritual and funerary sites in Roman Spain: discussing tradition, memory and identity in Roman society", C. Fenwick, M. Wiggins y D. Wythe (eds.), Proceedings of the Seventeenth Annual Theoretical Roman Archaeology Conference, 2007, 114.

Gell, A. 1998: Art and agency: an anthropological theory, Oxford.

Gombrich, E. H. 1999: The uses of images: studies in the social function of art and visual communication, London.

González-García, F. J. 2009: "Repensando el pasado: cambio social e iconografía guerrera en la Edad del Hierro del noroeste de la península Ibérica", Aquae Flaviae 41, 123-152.

González-Ruibal, A. 2004: "Artistic expression and material culture in celtic Gallaecia", E-Keltoi, 6. www.uwm.edu/Dept/celtic/ekeltoi/volumes.html, 1-38 (acceso 14-12-2010).

González-Ruibal, A. 2005: "El castro de Saceda y la jerarquización territorial de la segunda Edad del Hierro en el noroeste ibérico", Zephyrus 58, 267 284.

González-Ruibal, A. 2006-2007: “Galaicos. Poder y comunidad en el Noroeste de la Península Ibérica (1200 A.C.- 50 D.C.)", Brigantium 18-19.

Gosden, C. 2004: Archaeology and Colonialism: Cultural Contact from 5000 BC to the Present, Cambridge.
Gosden, C. y Marshall, Y. 1999: "The cultural biography of objects", World Archaeology 31 (2), 169-178.

Hamilton, N. 1996: "The Personal as Political", Cambridge Archaeological Journal 6 (2), 282-285.

Hamilton, N., Marcus, J., Bailey, D., Haaland, G., Haaland, R. y Ucko, P. 1996: “¿Can We Interpret Figurines?", Cambridge Archaeological Journal 6 (2), 281-307.

Hingley, R. 1996: "Ancestors and identity in the Later Prehistory of Atlantic Scotland: the reuse and reinvention of neolithic monuments and material culture", World Archaeology 28 (2), 231243.

Hingley, R. 2006: "Defining community: iron, boundaries and transformation in later prehistoric Britain", A. Harding, S. Sievers y N. Venclova (eds.), Enclosing the past. Inside and outside in Prehistory, Sheffield, 116-125.

Hingley, R. 2010: "Cultural diversity and unity: Empire and Rome", S. Hales y T. Hodos (eds.), Material culture and social identities in the ancient world, Cambridge, 54- 78.

Höck, M. 2003: “Os 'guerreiros galaico-lusitanos' na historia da investigacâo e interpretacâo: cultura castreja y Celtas", Madrider Mitteilungen 44, 5166.

Hodos, T. 2010: "Local and global perspectives in the study of social and cultural Identities", S. Hales y T. Hodos (eds.), Material culture and social identities in the ancient world, Cambridge, 3-31.

Koch, M. 2003: "Galläskischen Kriegerstatuen in ihrem literarisch -epigraphischen Zusammenhang", Madrider Mitteilungen 44, 67-86.

Kopytoff, I. 1986: "The cultural biography of things: commoditization as process", A. Appadurai (ed.), The Social Life of Things, Cambridge, 64-94.

Latour, B. 2001: La caja de Pandora: Ensayos sobre la realidad de los estudios de la ciencia, Barcelona.

Lewis-Williams, D. 2002: The mind in the cave: Consciousness and the origins of art, London.

Lincoln, B. 1991: Death, war and sacrifice, London.

Llanos, A. 2005: Mil años de vida en el poblado berón de la Hoya, La Guardia, Álava, Vitoria (soporte CD).

Llanos, A. 2007-2008: "El rito de las cabezas cortadas en el poblado de la Hoya", J.F. Fernández y J. Santos (eds.), Homenaje a Ignacio Barandiarán II, Vitoria.

López Cuevillas, F. 1989: La civilización céltica en Galicia, Madrid. 
Inomata, T. y Coben, L. S. 2006: "Overture: an invitation to the archaeological theather", T. Inimata y L. S. Coben (eds.): Archaeology of Performance, Oxford, 11-46.

Maluquer de Motes, J. 1954: "Los pueblos de la España céltica”, R. Menéndez Pidal (ed.), Historia de España, Vol. 1, Madrid.

Marco Simón, F. 1998: “Texto e imagen, ethos y creencias en la Hispania Indoeuropea de época republicana", J. Mangas (ed.), Italia e Hispania en la crisis de la república. III congreso hispano-italiano, Madrid, 387-402.

Marco Simón, F. 2006: "Intimidación y terror en la época de las Guerras Celtíberas", G. Urso (ed.), Terror et Pavor. Violenza, intimidazione, clandestinitá nel mondo antico, Milan, 197-213.

Marco Simón, F. y Baldellou, V. 1976: "El monumento ibérico de Binéfar", Pyrenae, 12, 73-90.

Martins, M. 1989: O castro do Barbudo, Vila Verde. Resultados das campanhas realizadas entre 1983 e 1985, Cadernos de Arqueologia, Monografias 3, Braga.

Martins, M. 1990: O povoamento proto-histórico e a romanização a bacia do curso médio do Cávado, Cadernos de Arqueologia, Monografias 5, Braga.

Martins, M. 1991: O povoado de Santo Ovídio (Fafe). Resultados dos trabalhos realizados entre 19801984, Cadernos de Arqueologia, Monografías 6, Braga.

Martins, M. y Silva, A. C. F. da 1984: "A estátua de guerreiro galaico de S. Julião (Vila Verde)", $\mathrm{Ca}$ dernos de Arqueologia, série 2, 1, 29-47.

Maya González, J. L. y Cuesta Toribio, F. 2001: El castro de La Campa Torres. Período prerromano, Gijón.

Megaw, J. V. S. 2003: "Where have all the warriors gone? Some aspects of stone sculpture from Britain to Bohemia", Madrider Mitteilungen 44, 269286.

Miller, D. 2005: Materiality, London.

Morphy, H. 2009: "Art as a mode of action: some problems with Gell's art and agency", Journal of material culture 14 (1), 5-27.

Myrberg, N. 2006: "The imperative way", A. Andrén, K. Jennbert, y C. Raudvere (eds.), Old Norse Religion in Long-term Perspectives: Origins, Changes, and Interactions, Lund, 45-49.

Nodar Nodar, C. 2004: "Estelas funerarias figuradas de época romana en Galicia", Actas del VII Congreso Internacional de Estelas funerarias, Santander, 209-224.

Noelke, P. 2003: Romanisation und Resistenz in Plas- tik, Architektur und Inschriften der Provincen des Imperium Romanum, Mainz am Rhein.

Orero Grandal, L. 2000: "Castromao (Celanova, Ourense)", Brigantium 12, 179-185.

Orero Grandal, L. 2007: "Intervención arqueolóxica no xacemento de Castromao, Campo de traballo arqueoloxico, Celanova (Ourense)", Actuacións Arqueolóxicas 2006, Santiago de Compostela, 29-30.

Orero Grandal, L. 2008: "Escavación e consolidación arqueolóxica no xacemento de Castromao, Celanova (Ourense)", Actuacións Arqueoloxicas 2007, Santiago de Compostela, 51-52.

Paço, A. do y Jalhay, E. 1955: “Tesouro monetário da Citânia de Sanfins", Anais da Academia Portuguesa da História, série II, 6, 189-275.

Parker Pearson, M. y Richards G. 1997: Architecture and order: approaches to social space, London.

Paris, P. 1903: Essai sur l'art et l'industrie de l'Espagne primitive, vol. 1, Paris.

Pena Graña, A. 2001: "Estatuas de guerreiros galaicos de granito con saios decorados", Anuario Brigantino 24, 39-49.

Pena Santos, A. de la 2003: Galicia. Prehistoria, castrexo e primeira romanización, Vigo.

Peralta Labrador, E. 2000: Los Cántabros antes de Roma, Madrid.

Pereira, F. A. 1908: "Novo material para o estudo da estatuaria e architetura dos castros do Alto-Minho", O Archeologo Português 13 (7), 202-244.

Queiroga, F. 2003: War and Castros. New approaches to the northwestern Portuguese Iron Age, Oxford.

Quesada Sanz, F. 2003: “¿Espejos de piedra?: Las imágenes de armas en las estatuas de los guerreros llamados galaicos", Madrider Mitteilungen 44, 87-112.

Redentor, A. 2008: "Inscrições sobre guerreiros lusitano-galaicos: leituras e interpretações", Revista Portuguesa de Arqueología 11 (2), 195-214.

Redentor, A. 2009: "Sobre o significado dos guerreiros lusitano-galaicos: o contributo da Epigrafía", Acta Palaeohispanica X. Palaeohispanica 9, 227246.

Revell, L. 2009: Roman imperialism and local identities, Cambridge.

Rey Castiñeiras, J. 1996: "Referencias de tempo na cultura material dos castros galegos", J. M. Hidalgo Cuñarro (coord.), A cultura castrexa galega a debate, Tui, 159-206.

Robb, J. 2009: "People of Stone: stelae, personhood, and society in prehistoric Europe", Journal Archaeological Method Theory 16, 162-183.

Robinson, M. 2003: "Place-making: the notion of centre. A typological investigation of means and 
meanings", S. Menin (ed.), Constructing place: mind and matter, London, 143-155.

Rodríguez Colmenero, A. 1993: "Historia da arte romana en Galicia. Escultura en relieve y bulto redondo", Galicia. Arte prehistórico y romano, IX, A Coruña, 375-475.

Rodríguez González, X. y Fariña Busto, F. 1986: “A Cidá do Castro de San Millán. Memorias de las excavaciones arqueológicas", Boletín Auriense 16, 39-89.

Rodríguez-Corral, J. 2009: A Galicia castrexa, Santiago de Compostela.

Rodríguez-Corral, J. 2010: La imaginación histórica: pueblos y culturas en el pensamiento Arqueológico, Tesis Doctoral inédita. Departamento de Historia I, Universidad Santiago de Compostela.

Rosaldo, A. 1980: Ilongot headhunting, 1883-1974. A study in society and history, Palo Alto.

Rykwert, J. 1985: La idea de ciudad. Antropología de la forma urbana en el mundo antiguo, Madrid.

Salinas de Frías, M. 2006: Los pueblos prerromanos de la península Ibérica, Madrid.

Sarmento, M. 1933: Dipersos, Coimbra.

Sarmento, M. 1986: "Estátuas militares en el jardím botánico da Ajuda", O Occidente. Revista Ilustrada de Portugal e do Extrangeiro 9, 283, 246-248.

Sarmento, M. 1999: Antíqua. Apontamentos de arqueología, Guimarães.

Schattner, T. 2004: "Novas aproximações às estatuas de guerreiros lusitano-galaicos", O Arqueólogo Português, série IV, 22, 9-66.

Scott, S. 2003: "Provincial art and Roman imperialism: an overview", S. Scott y J. Webster (eds.), Roman Imperialism and provincial art, Cambridge, $1-7$

Silva, A. C. F. da 1981: "Novos dados sobre a organização social castreja”, Portugalia 2-3 (Nova série), 83-94.

Silva, A. C. F. da 1986: A Cultura Castreja do Noroeste de Portugal, Paços de Ferreira.

Silva, A. C. F. da 1999: A Citânia de Sanfins. Museu Arqueológico da Citânia de Sanfins, Paços de Ferreira 22, 103-120.

Silva, A. C. F. da 2003: "Expressôes guerreiras da sociedades castreja", Madrider Mitteilungen 44, 33-40.

Snodgrass, A. 1992: The simbolism of the stupa, Nueva Delhi.

Soeiro, T. 2000-2001: "Monte Mozinho. A recuperação do sector B2", Portugália, Nova série, 21 32.
Sopeña Genzor, G. 2009: "Acerca de la amputación de la mano diestra como práctica simbólica. El caso de las guerras celtíbero-lusitanas", Salduie 8, 271-283.

Taboada Chivite, J. 1965: Escultura celto-romana, Vigo.

Taboada Cid, M. 1988-1989: "Estela funeraria antropomorfa do Muiño de San Pedro (Verín)", Boletín Auriense 18-19, 79-93.

Tilley, C. 2007: "Architectural order and the ordening of imagery in Malta and Ireland: a Comparative perspective", D. A. Barrowclough y C. Malone (eds.), Cult in Context: reconsidering ritual in archaeology, Oxford, 118-134.

Tilley, Ch. 2008: Body and image: explorations in landscape phenomenology 2, Oakland.

Tranoy A. 1981: La Galice romaine, recherches sur le Nord-Ouest de la Péninsule Ibérique dans l'Antiquité, Paris.

Tranoy A. 1988: "Du héros au chef, l'image du guerrier dans les sociétés indigènes du le nordouest de la péninsule ibérique ( $\mathrm{II}^{\mathrm{e}} \mathrm{S}$. avant J.-C.$\mathrm{I}^{\mathrm{er}}$ s. après J.-C.)", Le monde des images en Gaule et dans les provinces voisines, Paris, 219227.

Turner, V. 1967: The forest of symbols. Aspects of Ndembu ritual, New York.

Varela Gomes, M. 1997: "Estatuas-menhir antropomomórficas do Alto-Alentejo. Descobertas recientes eproblematicas", Brigantium 10, 255-279.

Vasconcellos, J. L. 1896: "Estátuas de guerreiros lusitanos", O Archeologo Português 2, 1, 1896, 2932.

Vasconcellos, J. L. 1913: Religiões da Lusitânia, III, Lisboa.

Villa Valdés, A. 2000: "Saunas castrexas en Asturias", C. Fernández Ochoa y V. García Entero (eds.), II Coloquio Internacional sobre termas romanas en el Occidente del Imperio, Gijón, 97-114.

Villa Valdés, A. 2002: "Periodización y registro arqueológico en los castros del occidente de Asturias", M. A. de Blas Cortina y A.Villa Valdés (eds.), Los poblados fortificados del Noroeste de la Península Ibérica: Formación y desarrollo de la Cultura Castreña. Coloquios de Arqueología en la Cuenca del Navia, Navia, 159-187.

Villa Valdés, A. 2003: "Depósito funerario y recinto fortificado de la Edad del Bronce en el castro de Samartín”, Trabajos de Prehistoria 60 (2), 143151.

Villa Valdés, A. 2007: “Intervención sobre los edificios termales del castro de Pendía (Boal): reexcavación, lectura y consolidación”, Excavaciones 
arqueológicas en Asturias 1999-2002, Oviedo: 268-294.

Webster, J. 2003: "Art as resistance and negotiation", S. Scott y J. Webster (eds.), Roman Imperialism and Provincial Art, Cambridge, 24-52.
Woolf, G. 1997: "Beyond Romans and natives", World Archaeology 28 (3), 339-350.

Woolf, G. 1998: Becoming Roman: The Origins of Provincial Civilization in Gaul, Cambridge.

Recibido: 12-05-2011

Aceptado: 08-11-2011 